\title{
\begin{tabular}{l|l} 
Mibraries & DSpace@MIT
\end{tabular}
}

\author{
MIT Open Access Articles
}

Mother-tongue books in Haiti: The power of
Kreyòl in learning to read and in reading to learn

The MIT Faculty has made this article openly available. Please share how this access benefits you. Your story matters.

Citation: DeGraff, Michel. "Mother-Tongue Books in Haiti: The Power of Kreyòl in Learning to Read and in Reading to Learn." PROSPECTS, vol. 46, no. 3-4, Dec. 2016, pp. 435-64.

As Published: http://dx.doi.org/10.1007/s11125-017-9389-6

Publisher: Springer Netherlands

Persistent URL: http://hdl.handle.net/1721.1/116462

Version: Author's final manuscript: final author's manuscript post peer review, without publisher's formatting or copy editing

Terms of use: Creative Commons Attribution-Noncommercial-Share Alike 


\title{
Mother-tongue books in Haiti:
}

\section{The power of Kreyòl in learning to read and in reading to learn}

\section{Michel DeGraff}

\author{
M. DeGraff \\ Linguistics and Philosophy \\ Massachusetts Institute of Technology \\ degraff@MIT.EDU
}

\begin{abstract}
This article aims at a deeper understanding of the importance of native languages in education and development, with Haiti as a case study. About half of Haiti's population is illiterate. Among ten children who enter the first grade, at most one (10\%) will graduate from high school; a large proportion will drop out of school at an early age. Language is a factor in such academic failure. Education in Haiti is carried out mostly in French, which is spoken fluently by at most $5 \%$ of the population, while the language spoken by $100 \%$ of the population, namely Haitian Creole (Kreyòl), is by and large excluded from the school system, in spite of legislation, official curricula, and various efforts from civil society to generalize the classroom use of Kreyòl. We hypothesize, based on comparative research on education in the mother tongue, that the systematic classroom use of Kreyòl — at all levels, but especially in early grades — promotes academic success in Haiti, as illustrated in this paper. This article reports on the results of an intervention to improve early-grade reading and writing in Haiti. This intervention is part of a larger project titled "Mother-Tongue Books: Learning to Read in Haiti" (MTB) with Christine
\end{abstract}


W. Low as principal investigator. The project promotes the collaborative production of books by Haitian school children in their native Kreyòl and the use of these books to enhance literacy gains in early grades. An assessment carried out during academic year 2012-2013 (DeGraff 2013b), using the Early Grade Reading Assessment (EGRA) instrument, showed that the first and second graders at Lekòl Kominotè Matènwa (LKM) in La Gonâve, Haiti, performed at a much higher level than their counterparts in five schools nearby. LKM is a pioneering MTB school where Haitian Kreyòl is used as the primary language of instruction. These initial results (referred to below as the "baseline assessment") spearheaded our intervention, whereby the MTB approach was introduced to the five other schools in the study. The final EGRA evaluation data show that the students in the five non-LKM schools, through the MTB intervention, substantially reduced the gap in their reading-and-writing levels vis-à-vis their LKM counterparts. In other words, the literacy skills of the students at the five non-LKM schools rose nearly to the level of those at LKM through the use of an intervention based on child-centered active-learning pedagogy with the systematic use of their native Kreyòl. In this paper, we analyze the data collected in the course of this project and their implications for policies to enhance reading and writing instruction in Haiti.

Keywords: Haiti, Haitian Creole (Kreyòl), literacy, instruction in the mother tongue, Mother Tongue Books (MTB), Lekòl Kominotè Matènwa (LKM), La Gonâve, Massachusetts Institute of Technology (MIT), National Science Foundation, Early Grade Reading Assessment (EGRA)

\section{Acknowledgments}

I thank the All Children Reading initiative and World Vision for funding the project Mother Tongue Books: Learning to read in Haiti (Principal Investigator: Christine W. Low). Heartfelt 
thanks to Chris for inviting me to collect and analyze the project's assessment data that are described in this article. I also thank the National Science Foundation for funding the work that first brought me to work with teachers and students in Matènwa in 2010 (NSF Award \# 1049718: http://www.nsf.gov/awardsearch/showAward.do?AwardNumber=1049718) and for funding subsequent work on technology-enhanced active learning in Kreyòl with STEM faculty at high schools and universities throughout Haiti (NSF Award \# 1248066: http://www.nsf.gov/awardsearch/showAward.do?AwardNumber=1248066). I thank my beloved Elena Geretti for her immensely gracious and indispensable help with nearly every aspect of this project; and I thank my amazing son, Nuriel, for his love and support and for patiently bearing with too many absences. Thank you, Nuriel, for understanding that every child in the world deserves an equal opportunity to succeed in school and life, with joy, creativity, and dignity. Of course, this work would have been impossible without the extraordinary team work of the "fanm vanyan", "gason vanyan", and "timoun vanyan" (courageous men, women, and pupils) at the Lekòl Kominotè Matènwa (LKM) in La Gonâve, Haiti, and at Friends of Matènwa in Massachusetts, with special thanks to Leslie Cohen for her editorial help on this paper and to Abner Sauveur and Christine Low, co-founders of LKM, for their vision toward quality education for all. I also thank three anonymous reviewers for extremely helpful comments that have greatly improved the form and content of this article. 
Unequal access to quality education is a global problem: it is one of the main sources of economic and political inequality in the world. One major factor at the root of this inequality is the marginalization of local languages in schools worldwide. There are some 200 million children throughout the world who are being taught in a language that they don't speak in their homes and communities; more than 2 billion people speak languages that are excluded in schools (Dutcher 2004; Walter and Benson 2012; UNESCO 2016). When children are taught in a language that they do not understand, their learning is often limited to rote memorization without creativity. This long-entrenched practice undermines children's prospects to become proficient readers and writers, in addition to causing them undue stress and devaluing their ancestral languages and cultures — which, in many cases, amounts to a violation of their human rights and to a sabotage of their identity and self-worth.

Haiti is one spectacular instance of this pedagogical, sociocultural, economic, and political predicament. Haiti is essentially a Haitian Creole-speaking nation even though it is often thought of as "Francophone". In reality, $100 \%$ of the population speaks Haitian Creole (Kreyòl) while less than 5\% are fluent in French. Yet, French is the primary language of classroom instruction and testing-likewise, it is the primary language for written transactions in government, courts, the formal economy, the press, etc. This is one root cause of massive academic failure, democratic instability, and dire levels of economic and political inequality. This makes Haiti an ideal test case for addressing this global problem of linguistic marginalization, especially when we consider that, in the Americas, Haiti shows the lowest level of literacy, the highest level of poverty, and the highest level of inequality (Ortiz and Cummins 2011; UNESCO 2002; Verner and Egset 2007; World Bank 2014). 
In this article I document extraordinary learning gains by a sample of Haitian children when they can benefit from the systematic use of their native Kreyòl in the teaching of literacy in

early grades. I start by providing some general background about Haiti and about crucial language and education issues there. Next, I describe the Mother Tongue Books (MTB) project, which is based on Kreyòl and on the active (and joyful!) participation of children in the production of Kreyòl texts about their everyday lives and environment. The benefits of this approach were first initially measured by comparing the reading-proficiency results in a school that had already been using the MTB approach (Lekòl Kominotè Matènwa [LKM] on the island of La Gonâve) with five other schools, on the same island, that had not been using the MTB method ("non-LKM schools"). I then present and analyze the results of the MTB intervention in the latter schools. I also consider some of this intervention's larger implications vis-à-vis education and development in Haiti. My hope, and that of all who worked on this project, is that the results described in this article will help inform curricular reforms and teacher training in Haiti, which in turn will promote better strategies for national development, including nation building through the generalized use of the national language in all sectors of society.

\section{Background: Language, education, and exclusion in Haiti}

Haiti was the first free black republic in the New World, becoming independent in 1804 after a revolution against the French colonists who had occupied the western half of the island of Hispaniola since the middle of the seventeenth century and who had turned it, in the eighteenth century, into the richest European colony. But in spite (or because) of this successful struggle for freedom in a world where slavery and colonization were still the norm since the arrival of Christopher Columbus in the Americas in 1492, Haiti has now become what's often referred to 
as "the poorest nation in the Western world". One root cause of this chronic impoverishment lies in the intersection between language, pedagogy, and ideology.

About half of the Haitian population is illiterate (CIA 2016; Huebler and Lu 2013). Among ten children who enter the first grade, at most one (10\%) will graduate from high school; a large proportion will drop out of school at an early age (GTEF 2010, p. 151). Language is a crucial factor in such academic failure. Indeed, education in Haiti is carried out mostly in French, which is spoken fluently by at most $5 \%$ of the population; while school systems often exclude Kreyòl, the language spoken by $100 \%$ of the population, especially in written materials and examinations - and the higher the grade level, the fewer written materials exist in Kreyòl.

This language issue is compounded by a pedagogical and ideological one: The age-old tradition in Haitian schools is rote memorization of French texts ("parcœurisme") that, too often, are largely irrelevant, or run counter, to students' daily lives and to their cultural background and identity (Jean-Pierre 2016). On top of their inhibiting effect on Haitian children's creativity, these texts induce alienation, with roots in Haiti's colonial history (Dejean 2006; Gourgues 2016; Jean-Pierre 2016). As for the teaching of literacy, it is often based on the memorization of letterto-sound correspondences, with students "reading" texts that they often do not understand. As documented in a World Bank/USAid study (Messaoud-Galusi and Miksic 2010), such methods create poor readers who, in turn, become poor learners for life.

More generally, rote-memorization methods with materials in a language that most students do not speak fluently are wholly inadequate for the promotion of the creative, criticalthinking, and problem-solving skills necessary for national development (DeGraff 2013a; Dejean 2006; Hebblethwaite 2012; Jean-Pierre 2016). In order for Haiti to become an "emergent country" by 2030 (an oft-repeated objective of Haiti's current leaders), Haiti's schools must 
produce professionals who understand what they have learnt and who can creatively and confidently apply their knowledge to local challenges. Yet the use of French as the language of instruction remains deeply entrenched in Haitian schools and children's textbooks in spite of the fact that the country's official curricula mandate the use of Kreyòl as language of instruction, especially in the early grades. This preference for French over Kreyòl is rooted in Haiti's colonial and neocolonial history and in its geopolitical role vis-à-vis Francophonie (Arthus 2012, 2014; DeGraff 2005, 2015a; Gourgues 2016; Jean-Pierre 2016).

It is, indeed, striking that the domination of French in the school system persists even after the 1987 Haitian Constiutution proclaimed Kreyòl an "official" language, alongside French, and described it as the only language that "bonds" all Haitians together. In a related vein, in 1979 the government made official a standard orthography for Kreyòl; furthermore, since the early 1980s, the country's official curricula (all written exclusively in French!) have prescribed the use of Kreyòl as initial language of instruction in primary schools. But, in practice, most books and most exams are still in French, which, as noted above, no more than 5\% of the population speaks fluently. Students from communities where people speak only Kreyòl (by far, the more typical situation) have little chance to succeed in school and even less chance to make it to university. Indeed, out of 10 children who start primary school, at most 1 will successfully complete secondary school (GTEF 2010, p. 151). From this perspective, language in Haiti becomes a vector of "élite closure" (à la Myers-Scotton 1993), helping to reproduce socioeconomic equalities across generations, with children from families where French is spoken at home having a headstart toward academic and economic success.

Looking at this problem from a global perspective, I argue, based on ample evidence (some of which UNESCO collected from 1953 onward) that the systematic use of mother 
tongues in education is essential, not only for the economic development of countries in the “Global South", such as Haiti, but also for the implementation of Education for All in developed nations, such as the U.S., with sizable populations of immigrants whose native languages are distinct from the primary languages of instruction in the "Global North".

One anonymous reviewer asks that I problematize the notion of "mother tongue" and "native speakers" in light of recent research such as that by Blommaert and Rampton who state, in their 2011 article on language and superdiversity, that "sociolinguists have long contested this idealisation, regarding it as impossible to reconcile with the facts of linguistic diversity, mixed language and multilingualism" (p. 4). As it turns out, the concept of superdiversity hardly applies to Haiti, where the population is, by and large, monolingual, with exposure to Kreyòl starting in the womb and throughout the speaker's life. This, in effect, does make Kreyòl a mother tongue for the majority of the population in Haiti. If we take, for example, the various definitions of "mother tongue" in Skutnabb-Kangas 1988, pp. 16-17), Kreyòl does qualify as the sole mother tongue for the majority of Haitians - for whom Kreyòl is indeed: (a) the language acquired from the womb, in the cradle, and at home; (b) the language in which they are most competent; (c) the language that they use, by far, the most (and, in most cases, the only language that they use); and (4) the language that defines their identity — as is obvious in many Kreyòl proverbs, such as "Kreyòl se lang rasin; Franse se lang achte", which means "Kreyòl is the language of our roots; French is the language that we buy". In a related vein, research documents that Kreyòl, in spite of its dialects, is relatively homogeneous, with no language barrier among Kreyòl speakers (Fattier 2000). One can, thus, safely assert that Kreyòl is the only (mother) tongue spoken by most Haitians, from cradle to grave; this is opposite of the superdiversity described in the Blommaert and Rampton article. 
Be that as it may, one unavoidable language-and-education problem is that, in the case of Creole languages, preference for the formerly colonial language is compounded by a dearth of quality pedagogical materials in local populations' native languages. This is similar to the situation with such indigenous languages as the Amerindian languages of Latin America or the Aboriginal languages of Australia. This state of affairs is not accidental: in addition to its (neo)colonial élite-closure function, the marginalization of these local languages is rooted in the age-old and still common belief that these languages are structurally and lexically impoverished and thus "inferior" to their European counterparts (DeGraff 2005, 2009, 2014; Migge, Léglise, and Bartens 2010). Even among preeminent intellectuals and political leaders in Creole-speaking communities, some believe that Creole languages such as Kreyòl in Haiti constitute a cognitive handicap for their speakers - even though this belief contradicts basic tenets in much of modern linguistics (DeGraff 2005). In one recent manifestation of such beliefs, the late Leslie Manigat (well-known Haitian historian and a former president of Haiti) is reported to have claimed that Haitian Creole is an "infirmity" (Zefi 2011). My own writings (DeGraff 2005, 2009, 2014, 2015a; DeGraff and Ruggles 2014) suggest that these beliefs are rooted more in geopolitical power struggles and in remnants of colonial and neocolonial ideologies than in adequate empirical data and theoretical considerations.

The empirical demonstration that the classroom use of Kreyòl improves literacy should thus create the potential for an extraordinary paradigm shift in our knowledge and perception of Creole languages, with a significant impact on teaching and learning in Creole-speaking communities (DeGraff 2013a, 2014; Neyfakh 2011). The marginalization of their native languages in school has traditionally deprived Creole-speaking communities of optimal access to 
quality education. Recall that there are more than 200 million children who are still being taught in a language that they do not speak fluently.

The transformative potential for global education is obvious: studies have long established that students learn better in their native languages (UNESCO 1953). Ongoing research continues to demonstrate the various ways whereby the use of students' native languages plays a key role in their education and their ability to express, explain, and construe logical arguments (Webb 2010). The use of native languages is also crucial for teachers, as we are currently researching and documenting in our ongoing NSF-funded project for STEM education in Kreyòl (http://haiti.mit.edu; https://www.facebook.com/mithaiti; http://www.nsf.gov/awardsearch/showAward.do?AwardNumber=1248066). Furthermore, researchers have convincingly argued that, by and large, countries that do not use their populations' mother tongues as languages of instruction are those with the worst records of academic achievement and national development (Hebblethwaite 2012; Walter 2008). Yet, in regard to the communities that most need access to quality education and quality materials in their native languages, policymakers have long neglected such momentous findings. In particular, one should ask: Why is it that, in Haiti and in many other impoverished communities in the world, so many students are still being taught in what is, in effect, a foreign language, which deprives them of equal opportunity to succeed academically and socioeconomically? Such pedagogical malpractice seems due to, among other things, a vicious cycle of reasoning — a selffulfilling prophecy:

1) Policymakers and development agencies often claim that education in local languages is difficult because of a lack of materials in these languages; and 
2) The relative dearth of materials in local languages is due to the aforementioned (erroneous) belief that these languages are structurally and lexically deficient and, thus, unable to express abstract scientific concepts.

This article is one more step toward breaking this vicious cycle: in it, I make explicit the advantages of Haiti's national language as an indispensable tool for education. Given the relatively low social status of local languages throughout the world, especially in postcolonial environments, and their disenfranchisement in formal education and other spheres where society creates and transmits knowledge and power (Babaci-Wilhite 2014; DeGraff 2005, 2009, 2014, 2015a), the study I report here should bear on language choices on a global scale. This is especially true for school systems that serve communities of people who speak such stigmatized local languages and where society still disenfranchises students socially, economically, and politically if they don't speak the language with the most cultural and intellectual capital. In line with current global comparative research on reading (see, e.g., Walter 2013), our major goal in this project, indeed, was to test the hypothesis that the teaching of literacy through child-centered interactive pedagogy in Kreyòl would enhance the learning gains of students in Haiti, especially those who are fluent in Kreyòl only. Such linguistic profile characterizes the vast majority of students in Haiti.

\section{Outline of the project and its rationale}

Messaoud-Galusi and Miksic's (2010) World Bank/USAid study, mentioned earlier, motivated the research that I present here. In that study, nearly half the children at the beginning of third grade could not read a single word; third graders were reading at an average of less than 23 words a minute. Messaoud-Galusi and Miksic stress that reading and writing proficiency is a key 
predictor of subsequent academic success. So the widespread and chronic failure in early-grade reading and writing in Haiti, as reported in their 2010 study, is bound to have dire ripple effects throughout the academic lives of the students and on the development prospects of the country.

With these data and observations in mind, I was struck that at Lekòl Kominotè Matènwa (LKM), where children are taught to read in their mother tongue, third graders were reading at an average of 60 words a minute - as documented in my 2010-2013 research funded by the National Science Foundation (DeGraff 2015b). This is one of the key factors that motivated the project I describe in this article.

This project was funded by the All Children Reading initiative led by USAid, World Vision, and Australian Aid. Christine W. Low was the project's principal investigator, and I was responsible for the evaluation component of the project. The title of the project is "Mother Tongue Books: Learning to Read in Haiti”. (Find more information, including a video, online at: http://allchildrenreading.org/innovators/friends-of-matenwa/; https://youtu.be/xmDO-X_d9YU.)

This project consisted of three main phases in succession:

Phase 1: An initial baseline assessment in which we compared the performance of the first and second graders at LKM with their counterparts in five nearby schools that use traditional (i.e., passive and teacher-centered) teaching methods with a mix of Kreyòl and French;

Phase 2: An intervention whereby we introduced LKM's MTB model to the five aforementioned non-LKM schools;

Phase 3: An evaluation to measure the effects of the intervention.

My role in the project was to lead the efforts in Phases 1 and 3 (more details below).

\section{Phase 1: Baseline assessment}


Our evaluation of the project started with an initial baseline survey, more fully described in a report dated March 13, 2013 (DeGraff 2013b). We measured this baseline with the Early Grade Reading Assessment (EGRA) instrument, and Mrs. Vana Edmond collected the data from November 5, 2012, to January 2, 2013. The EGRA is a reading evaluation instrument that the Research Triangle Institute (RTI) designed in 2006 (see, Gove and Wetterberg 2014). Mrs. Edmond is a fourth-grade teacher at LKM. She was trained as an EGRA enumerator in October 2012 in a workshop organized by RTI as part of its USAid-funded project Tout Timoun Ap Li (ToTAL) (RTI International 2014).

Table 1: Student enrollment in the baseline assessment for each school in the project

\begin{tabular}{|l|c|c|c|}
\hline School Name & 1st graders & 2nd graders & TOTAL \\
\hline Baptiste Mare-Sucrin (BM) & 6 & 11 & 17 \\
\hline Joli Verger (JB) & 27 & 54 & 76 \\
\hline La Pléiade (LP) & 41 & 35 & 23 \\
\hline École Nationale Mare-Sucrin (NM) & 8 & 15 & 21 \\
\hline Vision Fred (VF) & 11 & 10 & 37 \\
\hline Lekòl Kominotè Matènwa (LKM) & 18 & 19 & 25 \\
\hline TOTAL & 111 & 144 & 255 \\
\hline
\end{tabular}

For that initial report of March 2013, Mrs. Edmond administered the EGRA test, as a baseline assessment, to 255 pupils in 6 schools in La Gonâve: 37 pupils at LKM and 218 pupils in 5 other schools - 1 public (or "national") and 4 private. (Previous reports [such as DeGraff 2013b] mistakenly reported the total number of students at 218; however, 218 is the total number of non-LKM students - which, when added to the 37 LKM students, brings the total students in the baseline to 255.) I will continue to refer to these 5 schools as the "non-LKM" schools, with the LKM students' serving as a positive control to help evaluate the MTB intervention. 
Tables $2 \mathrm{a}$ and $2 \mathrm{~b}$, below, summarize the results of the baseline EGRA assessment. For the assessment, we used 8 out of the 9 subtests of the EGRA instrument. We administered the dictation subtest, but it is not scored-RTI has not yet devised a scoring formula for this subtest. Here are the 8 subtests and how they are scored-I give more details about these subtests below, in the section on the final evaluation, for which we used the same subtests.

1) Letter-name knowledge, measured by the number of correctly identified graphemes in 1 minute, from a list of 100 graphemes

2) Phoneme segmentation, measured by the number of phonemes correctly identified at the beginning of a word, out of 10 words

3) Grapheme-phoneme correspondence, measured by the number of correctly identified phonemes in 1 minute, out of a list of 100 graphemes

4) Reading of familiar words, measured by the number of correctly read words, out of 50 words, in 1 minute

5) Reading of unfamiliar (invented) words, measured by the number of correctly read words, out of 50 words, in 1 minute

6) Short-story reading (61-word story), measured by the number of correctly read words in 1 minute

7) Reading comprehension, measured by the number of correct answers out of 5

8) Listening comprehension, measured by the number of correct answers out of 5

Table 2a: Overall results, as medians, from baseline assessment, for subtests (1)-(4), in academic year 2012-2013. The LKM results are in the bottommost row, to be compared with the results in the non-LKM schools in the other rows. 


\begin{tabular}{|l|c|c|c|c|c|c|c|c|}
\hline & \multicolumn{2}{|c|}{$\begin{array}{c}\text { Letter-name knowledge } \\
\text { (correct letter }\end{array}$} & \multicolumn{2}{|c|}{$\begin{array}{c}\text { Phoneme segmentation } \\
\text { (correct answers/10) }\end{array}$} & $\begin{array}{c}\text { Letter-phoneme correspondence } \\
\text { (correct phomemes/min) }\end{array}$ & $\begin{array}{c}\text { Familiar-word identification } \\
\text { (correct words/min) }\end{array}$ \\
\hline School/Grade & 1st & 2nd & 1st & 2nd & 1st & 2nd & 1st & 2nd \\
\hline BM & 11.5 & 12 & 2.5 & 3 & 10 & 8 & 1 & 5 \\
\hline JV & 5 & 12.5 & 0 & 0 & 4 & 7 & 0 & 2 \\
\hline LP & 7 & 22 & 1 & 2 & 7 & 10 & 1 & 8 \\
\hline NM & 4.5 & 11 & 0 & 2 & 5 & 8 & 0.5 & 3 \\
\hline VF & 7 & 10 & 4 & 2.5 & 6 & 8 & 1 & 1.5 \\
\hline LKM & 14.5 & 33 & 10 & 10 & 21.5 & 60 & 5 & 28 \\
\hline
\end{tabular}

BM: Baptiste Mare-Sucrin; JV: Joli Verger; LP: La Pléïade; NM: École Nationale Mare-Sucrin; VF: Vision Fred; LKM: Lekòl Kominotè Matènwa.

Table 2b: Overall results, as medians, from baseline assessment, for subtests (5)-(8), in academic year 2012-2013. The LKM results are in the bottom-most row, to be compared with the results in the non-LKM schools in the other rows.

\begin{tabular}{|l|c|c|c|c|c|c|c|c|}
\hline & $\begin{array}{c}\text { Invented-word decoding } \\
\text { (correct words/min) }\end{array}$ & \multicolumn{2}{|c|}{$\begin{array}{c}\text { Short-story reading } \\
\text { (correct words/min) }\end{array}$} & $\begin{array}{c}\text { Reading comprehension } \\
\text { (correct answers/5) }\end{array}$ & $\begin{array}{c}\text { Oral-story comprehension } \\
\text { (correct answers/5) }\end{array}$ \\
\hline School/Grade & 1st & 2nd & 1st & 2nd & 1st & 2nd & 1st & 2nd \\
\hline BM & 0 & 1 & 0 & 0 & 0 & 0 & 3.5 & 4 \\
\hline IV & 0 & 0.5 & 0 & 0 & 0 & 0 & 4 & 5 \\
\hline LP & 0 & 4 & 0 & 4 & 0 & 0 & 4 & 5 \\
\hline VF & 0 & 0 & 0 & 0 & 0 & 0 & 4.5 & 4 \\
\hline LKM & 0 & 0 & 0 & 0 & 0 & 0 & 4 & 5 \\
\hline
\end{tabular}

BM: Baptiste Mare-Sucrin; JV: Joli Verger; LP: La Pléïade; NM: École Nationale Mare-Sucrin; VF: Vision Fred; LKM: Lekòl Kominotè Matènwa.

Overall, both Tables $2 \mathrm{a}$ and $2 \mathrm{~b}$ show that the performance of the LKM students was significantly higher than the performance of the non-LKM students. Interestingly, the results of the oral story comprehension, which by and large does not seem to depend on literacy skills, are similar across the LKM and the non-LKM students, showing that both groups have comparable cognitive abilities, outside of reading - this is a point that I will revisit when I analyze the postintervention assessment data.

Meanwhile, I must stress that the overall results of the baseline assessment show that the reading levels of the students in the five non-LKM schools were extremely low. Many children, even in the second grade, seemed unable to read any word at all. And in two schools almost 
every student was unable to read any word in a short story. These data converge with the low averages in previous studies on reading and writing levels in Haiti (e.g., Messaoud-Galusi and Miksic 2010).

Faced with these data, it was clear that the five non-LKM schools required immediate remedial action. We hypothesized that MTB-based methods - teaching literacy through childcentered interactive pedagogy and collaborative production of books in Kreyòl—would improve the reading levels of the first and second graders at the non-LKM schools. So we planned to measure the reading levels of that cohort of students the following academic year, 2013-2014, i.e., when they reached the second and third grades, respectively.

\section{Phase 2: The intervention (overview)}

The basic intervention in the MTB project consists of children's production of illustrated storybooks in Kreyòl, alongside the use of these storybooks in their classrooms. Students create these books with the help of teachers, as a collaborative effort. The books are trilingual: in Kreyòl, French, and English. The French and English translations are produced by LKM teachers and by educators at partner schools and other institutions, in Haiti and in the U.S., that support LKM's efforts. The stories in these books are based on the children's own experiences and environments and on their own spontaneous storytelling. In the classroom, the children act out their stories as they are read aloud. The book-writing process includes Writers Workshop sessions, where students also produce journals alongside Mother Tongue Books. (Interactive read-aloud sessions are another crucial part of the MTB project; teachers read aloud samples of other texts to the students and ask them questions about the text at preprogrammed points. The 
schools use these read-alouds in tandem with independent reading sessions, with teachers working with small groups, as needed. Children also read their stories in weekly all-school meetings that are open to the entire community — for one example, see this video at https://youtu.be/KHU-GHeQEQs. For more details about the MTB approach, see Friends of Matènwa's 2012 proposal, "Mother Tongue Books: Learning to Read in Haiti”; for a video presentation and sample of these Mother Tongue Books, see: https://youtu.be/xmDO-X_d9YU; http://educavision.com/catalog.php?c=8\&b=SP369 ; http://www.matenwa.org/\#!untitled/c2q4.)

\section{Phase 3: Final evaluation}

The final evaluation was carried out after expanding the MTB intervention to the five non-LKM schools through an LKM-led effort. In the sections below I analyze the updated EGRA data that Mrs. Edmond collected from the same pool of pupils (now in second and third grades) in June and July 2014.

Table 3: Student enrollment in the final evaluation for each school in the project

\begin{tabular}{|l|c|c|c|}
\hline School Name & 2nd graders & 3rd graders & TOTAL \\
\hline Baptiste Mare-Sucrin (BM) & 9 & 8 & 17 \\
\hline Joli Verger (JB) & 33 & 51 & 54 \\
\hline La Pléïade (LP) & 30 & 22 & 13 \\
\hline École Nationale Mare-Sucrin (NM) & 6 & 7 & 24 \\
\hline Vision Fred (VF) & 12 & 12 & 32 \\
\hline Lekòl Kominotè Matènwa (LKM) & 16 & 119 & 225 \\
\hline TOTAL & 106 & & 35 \\
\hline
\end{tabular}

Note: We could not recover the identities and affiliation of 14 data points from the online database. These losses are due to a combination of human error and technological failure. 
Table 4a: Overall results, as medians, from final evaluation, for subtests (1)-(4), in academic year 2013-2014.

\begin{tabular}{|l|c|c|c|c|c|c|c|c|}
\hline & $\begin{array}{c}\text { Letter-name knowledge } \\
\text { (correct letter names/min) }\end{array}$ & $\begin{array}{c}\text { Phoneme segmentation } \\
\text { (correct answers/10) }\end{array}$ & $\begin{array}{c}\text { Letter-phoneme correspondence } \\
\text { (correct phonemes/min) }\end{array}$ & $\begin{array}{c}\text { Familiar-word identification } \\
\text { (correct words/min) }\end{array}$ \\
\hline School/Grade & 2nd & 3rd & 2nd & 3rd & 2nd & 3rd & 2nd & 3rd \\
\hline BM & 35 & 57.5 & 10 & 9 & 49 & 46 & 27 & 36 \\
\hline IV & 22 & 34 & 7 & 9 & 15 & 22 & 8 & 12 \\
\hline LP & 34.5 & 51 & 10 & 10 & 30.5 & 53.5 & 21.5 & 44.9 \\
\hline NM & 28.5 & 35 & 9 & 10 & 28.5 & 43 & 17 & 29 \\
\hline VF & 34.5 & 37 & 10 & 10 & 57 & 51.5 & 38.5 & 26 \\
\hline LKM & 33 & 57 & 10 & 10 & 44 & 68 & 30 & 55.6 \\
\hline
\end{tabular}

Note: The LKM results are in the bottommost row, to be compared with the results in the non-LKM schools in the other rows.

Table 4b: Overall results, as medians, from final evaluation, for subtests (5)-(8), in academic year 2013-2014.

\begin{tabular}{|l|c|c|c|c|c|c|c|c|}
\hline & $\begin{array}{c}\text { Invented-word decoding } \\
\text { (correct words/min) }\end{array}$ & \multicolumn{2}{|c|}{$\begin{array}{c}\text { Short-story reading } \\
\text { (correct words/min) }\end{array}$} & \multicolumn{2}{|c|}{$\begin{array}{c}\text { Reading comprehension } \\
\text { (correct answers/5) }\end{array}$} & \multicolumn{2}{|c|}{$\begin{array}{c}\text { Oral-story comprehension } \\
\text { (correct answers/5) }\end{array}$} \\
\hline School/Grade & 2nd & 3rd & 2nd & 3rd & 2nd & 3rd & 2nd & 3rd \\
\hline BM & 20 & 27 & 33 & 52.5 & 2 & 3.5 & 5 & 5 \\
\hline IV & 5 & 7 & 4 & 10 & 0 & 0 & 5 & 5 \\
\hline LP & 17.5 & 28.5 & 26 & 62.6 & 2 & 4 & 5 & 5 \\
\hline NM & 17 & 23 & 20.5 & 29 & .5 & 2 & 5 & 5 \\
\hline VF & 25.5 & 16.5 & 45 & 34.5 & 3 & 2 & 5 & 5 \\
\hline LKM & 26 & 37 & 37.5 & 73.2 & 2.5 & 5 & 5 & 5 \\
\hline
\end{tabular}

Note: The LKM results are in the bottommost row, to be compared with the results in the non-LKM schools in the other rows.

The final-evaluation results (summarized in Tables $4 \mathrm{a}$ and $4 \mathrm{~b}$ above, to be compared with Tables $2 \mathrm{a}$ and $2 \mathrm{~b}$ from the baseline assessment, repeated below for convenience) clearly show that the MTB project's Kreyòl-based teaching methods substantially increased the reading levels of the pupils in the 5 non-LKM schools and the 10 pilot classrooms therein. 
Table 2a: Overall results, as medians, from baseline assessment, for subtests (1)-(4), in academic year 2012-2013.

\begin{tabular}{|l|c|c|c|c|c|c|c|c|}
\hline & \multicolumn{2}{|c|}{$\begin{array}{c}\text { Letter-name knowledge } \\
\text { (correct letter names/min) }\end{array}$} & $\begin{array}{c}\text { Phoneme segmentation } \\
\text { (correct answers/10) }\end{array}$ & $\begin{array}{c}\text { Letter-phoneme correspondence } \\
\text { (correct phomemes/min) }\end{array}$ & $\begin{array}{c}\text { Familiar-word identification } \\
\text { (correct words/min) }\end{array}$ \\
\hline School/Grade & 1st & 2nd & 1st & 2nd & 1st & 2nd & 1st & 2nd \\
\hline BM & 11.5 & 12 & 2.5 & 3 & 10 & 8 & 1 & 5 \\
\hline JV & 5 & 12.5 & 0 & 0 & 4 & 7 & 0 & 2 \\
\hline LP & 7 & 22 & 1 & 2 & 7 & 10 & 1 & 8 \\
\hline NM & 4.5 & 11 & 0 & 2 & 5 & 8 & 0.5 & 3 \\
\hline VF & 7 & 10 & 4 & 2.5 & 6 & 8 & 1 & 1.5 \\
\hline LKM & 14.5 & 33 & 10 & 10 & 21.5 & 60 & 5 & 28 \\
\hline
\end{tabular}

BM: Baptiste Mare-Sucrin; JV: Joli Verger; LP: La Pléïade; NM: École Nationale Mare-Sucrin; VF: Vision Fred; LKM: Lekòl Kominotè Matènwa.

Note: The LKM results are in the bottommost row, to be compared with the results in the non-LKM schools in the other rows.

Table 2b: Overall results, as medians, from baseline assessment, for subtests (5)-(8), in academic year 2012-2013.

\begin{tabular}{|l|c|c|c|c|c|c|c|c|}
\hline & $\begin{array}{c}\text { Invented-word decoding } \\
\text { (correct words/min) }\end{array}$ & \multicolumn{2}{|c|}{$\begin{array}{c}\text { Short-story reading } \\
\text { (correct words/min) }\end{array}$} & $\begin{array}{c}\text { Reading comprehension } \\
\text { (correct answers/5) }\end{array}$ & $\begin{array}{c}\text { Oral-story comprehension } \\
\text { (correct answers/5) }\end{array}$ \\
\hline School/Grade & 1st & 2nd & 1st & 2nd & 1st & 2nd & 1st & 2nd \\
\hline BM & 0 & 1 & 0 & 0 & 0 & 0 & 3.5 & 4 \\
\hline IV & 0 & 0.5 & 0 & 0 & 0 & 0 & 4 & 5 \\
\hline LP & 0 & 4 & 0 & 4 & 0 & 0 & 4 & 5 \\
\hline NM & 0 & 0 & 0 & 0 & 0 & 0 & 4.5 & 4 \\
\hline VF & 0 & 0 & 0 & 0 & 0 & 0 & 4 & 4 \\
\hline LKM & 0.5 & 21 & 0.5 & 31 & 0 & 2 & 5 & 5 \\
\hline
\end{tabular}

BM: Baptiste Mare-Sucrin; JV: Joli Verger; LP: La Pléïade; NM: École Nationale Mare-Sucrin; VF: Vision Fred; LKM: Lekòl Kominotè Matènwa.

Note: The LKM results are in the bottommost row, to be compared with the results in the non-LKM schools in the other rows.

The contrast between the baseline-assessment data and the final-evaluation results leaves no doubt about the positive effect of the intervention. In the baseline assessment, the LKM pupils performed at a much higher level than their counterparts in the five non-LKM schools in the study. In contrast, the final evaluation shows that the latter students substantially caught up with their LKM counterparts in terms of their reading proficiency. 


\section{Analysis of the results}

As in the baseline assessment, the instrument for the final evaluation is the Early-Grade Reading Assessment (EGRA) developed by the Research Triangle Institute (RTI), and the enumerator for the MTB project was, again, Mrs. Vana Edmond (LKM).

I now report on the eight aforementioned subtests of the EGRA instrument and compare them with the corresponding data from the baseline assessment.

\section{Results of letter-name subtest (Figures $1 a$ and $1 b$ )}

This part of the assessment evaluates students' knowledge of letter names. (Please see the appendix for an analysis of letter names in French vs. Kreyòl and about the advantages of Kreyòl's transparent phonemic orthography over that of French's opaque orthography. This appendix suggests a pedagogically sound nomenclature for Kreyòl letter names while further encouraging the use of Kreyòl as the primary medium of instruction for Kreyòl-speaking children, especially for the learning of literacy in the earliest grades.) In this letter-name subtest, the enumerator gives the student a grid that displays 100 occurrences of valid letters or letter combinations from the Kreyòl alphabet and asks the student to identify as many of these occurrences as possible from the list of 32 graphemes of the Kreyòl alphabet. This is a timed test that lasts 1 minute. If the student goes through the entire minute giving answers (i.e., when the time remaining is 0 out of 60 ), the score (correct answers per minute) is the total of correct answers. If the student stops or is made to stop (after 10 consecutive mistakes) before reaching the 1-minute mark (in order to avoid stress on the children), or if the student goes through the entire grid in less than 1 minute, the score is calculated according to the following formula: $x /(1-$ ("time remaining"/60)), where $x$ is the number of correct answers and "time remaining" is the 
number of seconds remaining until the 60 -second time mark. Similar formulas apply to other timed tests in the evaluation (letter-name knowledge, reading of familiar words, reading of unfamiliar words, short-story reading).

In the letter-knowledge subtest, the "Tangerine"-based (http://www.tangerinecentral.org) evaluation instrument has an autostop feature that is activated (i.e., the subtest automatically stops) if the student gives incorrect answers for the first 10 items in the grid of stimuli.

Figures $1 \mathrm{a}$ and $1 \mathrm{~b}$, below, summarize the results for this test across the five schools. In Figure 1a, the data from the LKM students are shown in the rightmost and highlighted bar (LKM students are shown in highlighted bars in all the graphs below).

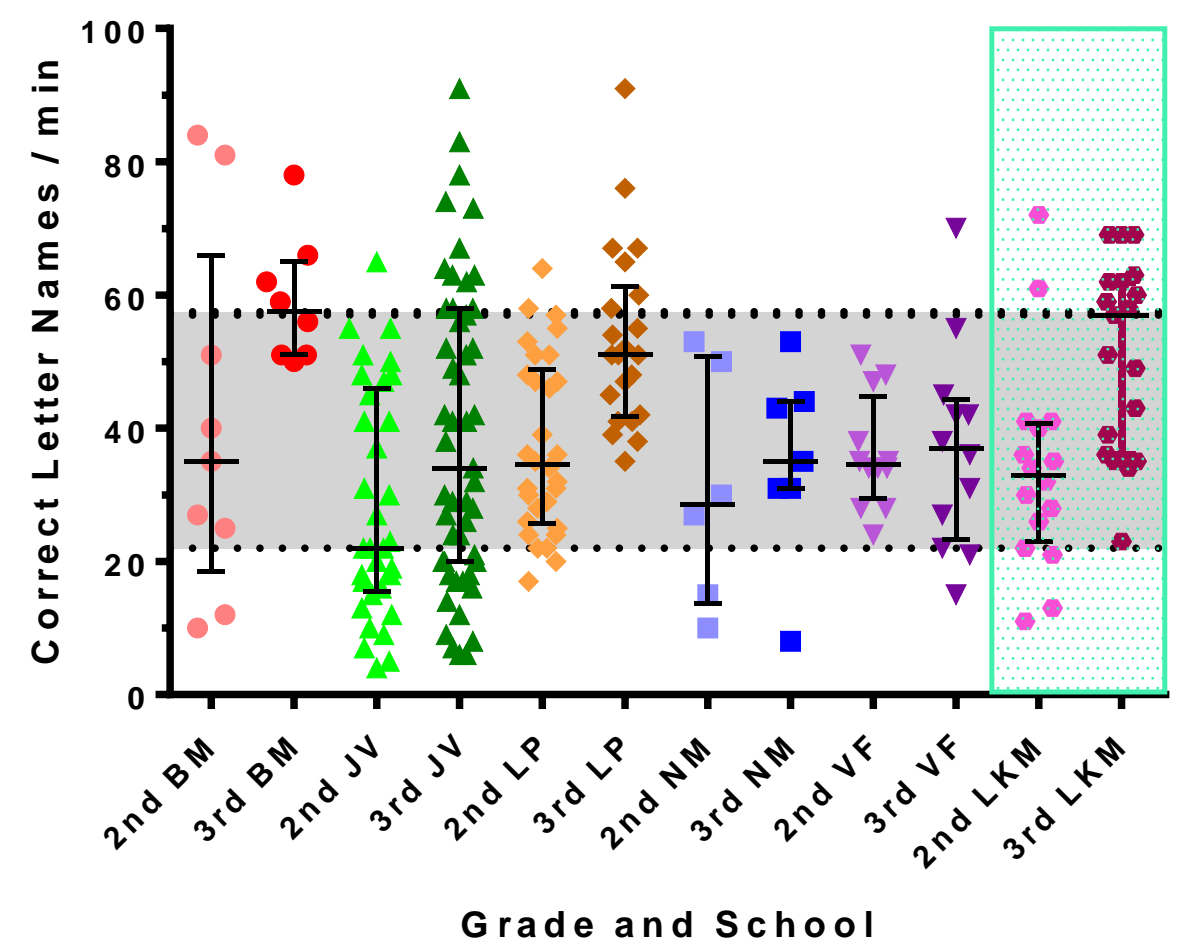

Figure 1a. Knowledge of letter names in 2014

In Figure 1a, consider the median scores for the second and third graders in all the five non-LKM schools in 2013-2014. The set of median scores falls in the range from 22 to 57.5 
correct letter names per minute (see grey shade in the graph). As in the baseline, this article focuses on median (rather than average) scores because outliers affect average scores in the context of small group sizes such as the ones in this report.

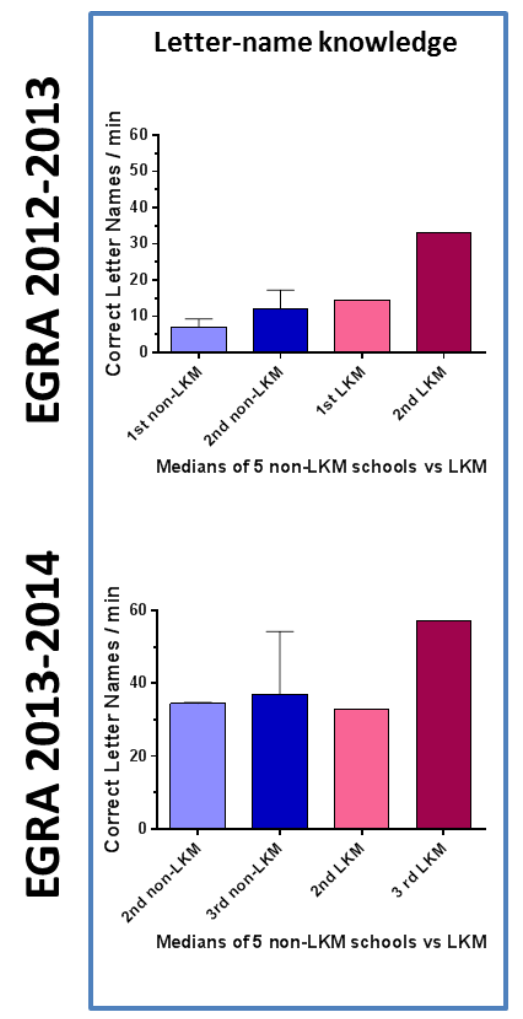

Figure 1b. LKM/non-LKM medians for letter-name knowledge from baseline assessment (2012-2013, top graph) to final evaluation (2013-2014, bottom graph)

In Figure $1 b$ (as in Figures $2 b, 3 b, 4 b, 5 b, 6 b, 7 b$, and $8 b$ below) the median shown for the five non-LKM schools is the median of their five medians. Now, consider the medians for these very same cohorts in the preceding academic year (the first and second graders in nonLKM schools in 2012-2013). These medians had fallen in a range from 4.5 to 22 (see Table 2a).

A certain amount of progress from one year to the next is expected, given that the students have matured and one would anticipate their improvement in any case. But what's most noteworthy in the above figure, keeping in mind the differences in performances between LKM 
and non-LKM students in the baseline data (see Tables $2 \mathrm{a}$ and $2 \mathrm{~b}$ ), is the fact that the second graders in the five non-LKM schools in 2013-2014 now perform at approximately the same levels as their LKM counterparts, even though the LKM second graders had performed much better than the non-LKM ones the preceding year. Indeed, the LKM second graders show a median of 33 correct letter names per minute (Figure 1b, bottom graph, light and dark magenta bars), whereas the second graders in the five non-LKM schools show a median of 34.5

(Figure 1b, bottom graph, light and dark blue bars). We see such progress among the non-LKM second graders most clearly in Figure 1b, where, in academic year 2013-2014, the non-LKM second graders perform at a level slightly higher than their counterparts at LKM. In this figure, and throughout the text below, the term "median of the 5 non-LKM schools" refers to the median of the five medians of these schools. As for the third graders in the non-LKM schools, there's progress as well, but not as spectacular: 37 for non-LKM versus 57 for LKM. This difference between the progress of the younger pupils versus the older ones is consistent across most of the subtests.

\section{Results of subtest on phoneme segmentation (Figures $2 a$ and $2 b$ )}

In this subtest, the enumerator asked students to identify the initial phoneme (the onset of the first syllable) of 10 Kreyòl words. The student listens to the enumerator pronounce each word twice, and then the student has to pronounce the initial phoneme. For example, the initial phoneme in the Kreyòl word "soup" is / s /, and the student has to pronounce [ sssss ] in order to identify that initial / s /. In this subtest, the Tangerine's autostop feature is triggered if the student gives incorrect answers for the first 5 words. 


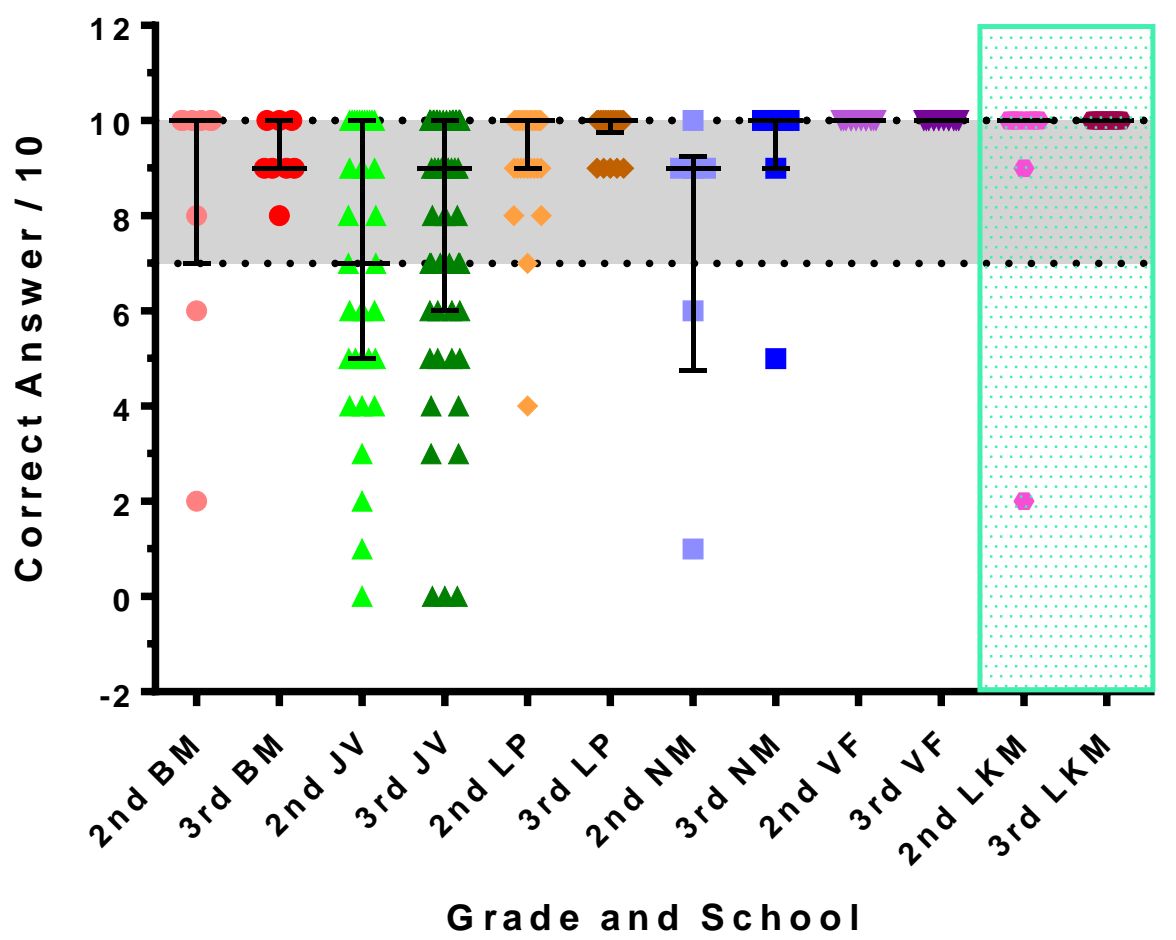

Figure 2a. Phoneme segmentation (identification of initial phonemes) in 2014

In Figure 2a, the set of median scores for the second and third graders in the five nonLKM schools in 2013-2014 fall in the range of 7 to 10 correct answers out of 10 (see grey shade in the graph).

In the baseline assessment in 2012-2013, this subtest and the next one (on graphemephoneme correspondences) were among the most difficult for first and second graders across all non-LKM schools. 


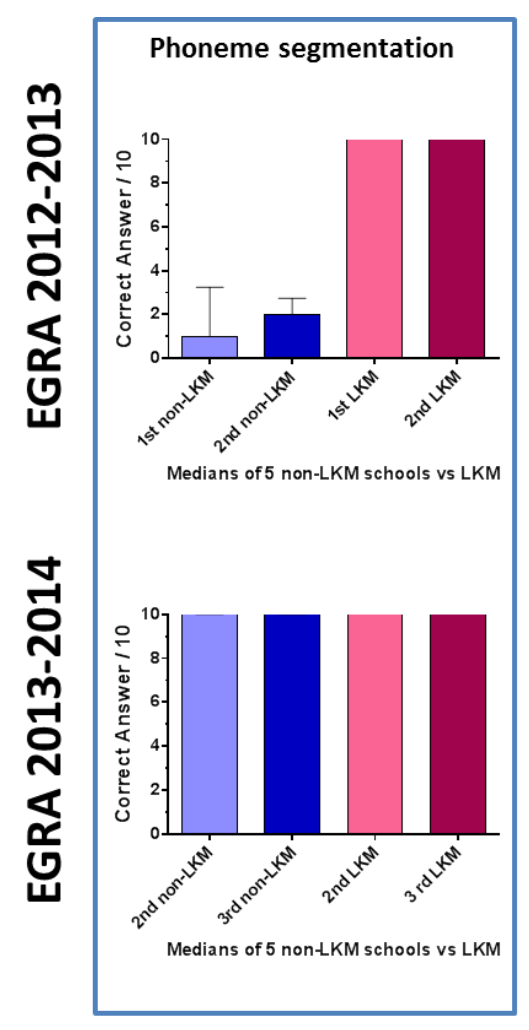

Figure 2b. LKM/non-LKM medians for phoneme segmentation from baseline assessment (2012-2013, top graph) to final evaluation (2013-2014, bottom graph)

In the non-LKM schools, the phoneme-segmentation subtest had median scores equal to 1 and 2 for the first and second graders, respectively (Figure 2b, top graph, light and dark blue bars). (By "median scores", we mean the medians of the 5 medians for each grade.) This is in stark contrast with the LKM students, all of whom could give the right answers for all the 10 stimuli for this particular subtest on identifying the initial phoneme of words (Figure 2b, top graph, light and dark magenta bars). But, now, the non-LKM second and third graders in 2013-2014 are at the same levels as their LKM counterparts: all the pupils in both groups (LKM and non-LKM schools) have perfect scores (i.e., 10/10), as summarized in Figure 2b, bottom graph. 


\section{Results of subtest on grapheme-phoneme correspondences (Figures $3 a$ and $3 b$ )}

This is another timed test (60 seconds, like all timed tests in EGRA) based on a grid that displays 100 occurrences of valid letters or letter combinations from Kreyòl's 32-grapheme alphabet. The student is asked to identify the phonemes associated with as many of these graphemes as possible. For example, the phoneme corresponding to the grapheme $<\mathrm{m}>$ is / $\mathrm{m} /$ and the student must utter [ $\mathrm{mmmm}$ ] in order to identify this phoneme / $\mathrm{m} /$. In this test, students' giving incorrect answers for the first 10 items in the grid of stimuli will trigger the Tangerine's autostop feature..

In Figure 3a below, the median scores for the second and third graders in all of the five non-LKM schools in 2013-2014 range between 15 and 57 correct phonemes in 1 minute (see gray shade in the graph).

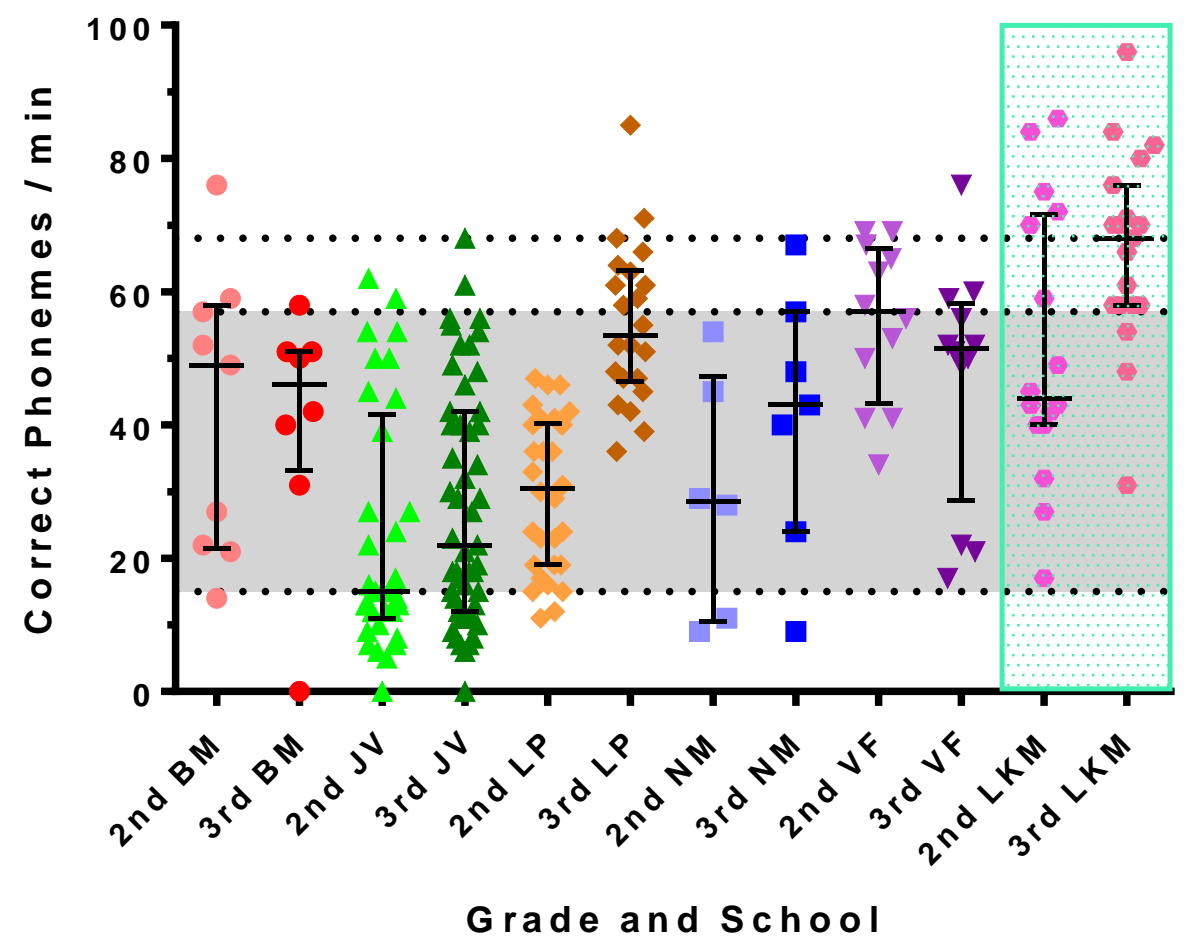


Figure 3a. Knowledge of letter-phoneme correspondence in 2014

In the baseline assessment, this subtest, like the previous subtest, was very difficult for the non-LKM students. In 2012-2013 pupils in all five non-LKM schools had a tendency to answer by giving the letter names instead of pronouncing the phoneme associated with the letter.

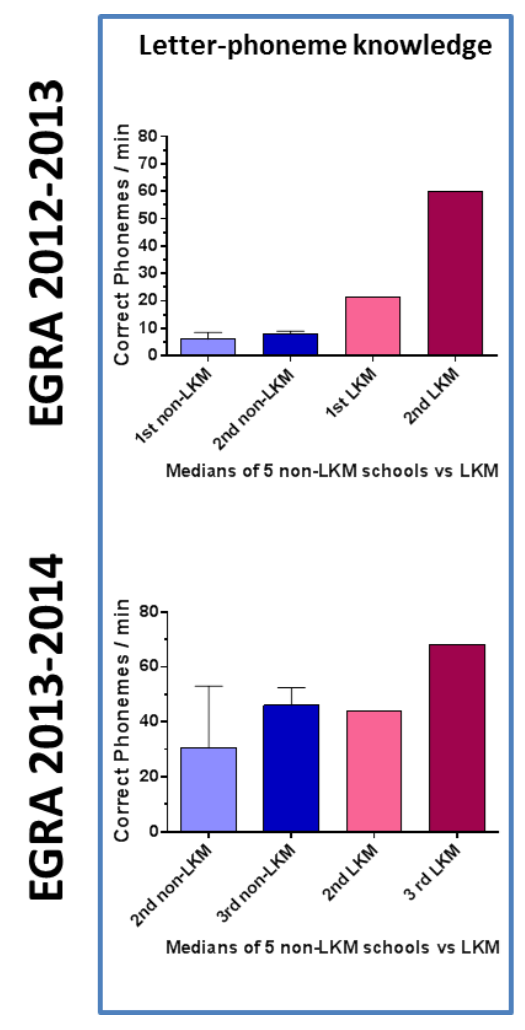

Figure 3b. LKM/non-LKM medians for letter-phoneme correspondence from baseline assessment (2012-2013, top graph) to final evaluation (2013-2014, bottom graph)

The median scores for the then first and second grades for the five non-LKM schools (i.e., the medians of the 5 medians for each grade) were 6 and 8 , respectively (Figure 3b, top graph, light and dark blue bars); whereas, the median score for both the first and second graders at LKM was 21.5 and 60 , respectively (Figure 3b, top graph, light and dark magenta bars). The contrast 
between 2012-2013 (Figure 3b, top graph) and 2013-2014 (Figure 3b, bottom graph) is clear: the second and third graders at non-LKM schools in 2013-2014 had median scores of 30.5 and 46, respectively (Figure 3b, bottom graph, light and dark blue bars), as compared to the respective scores of 44 and 68 for the second and third graders at LKM (Figure 3b, bottom graph, light and dark magenta bars).

Reading offamiliar words (Figures $4 a$ and $4 b$ )

In this subtest, the student is asked to read each word in isolation from a sequence of 50 familiar words of relatively high frequency. In this test, students' giving incorrect answers for the first 5 words triggers the Tangerine's autostop feature.

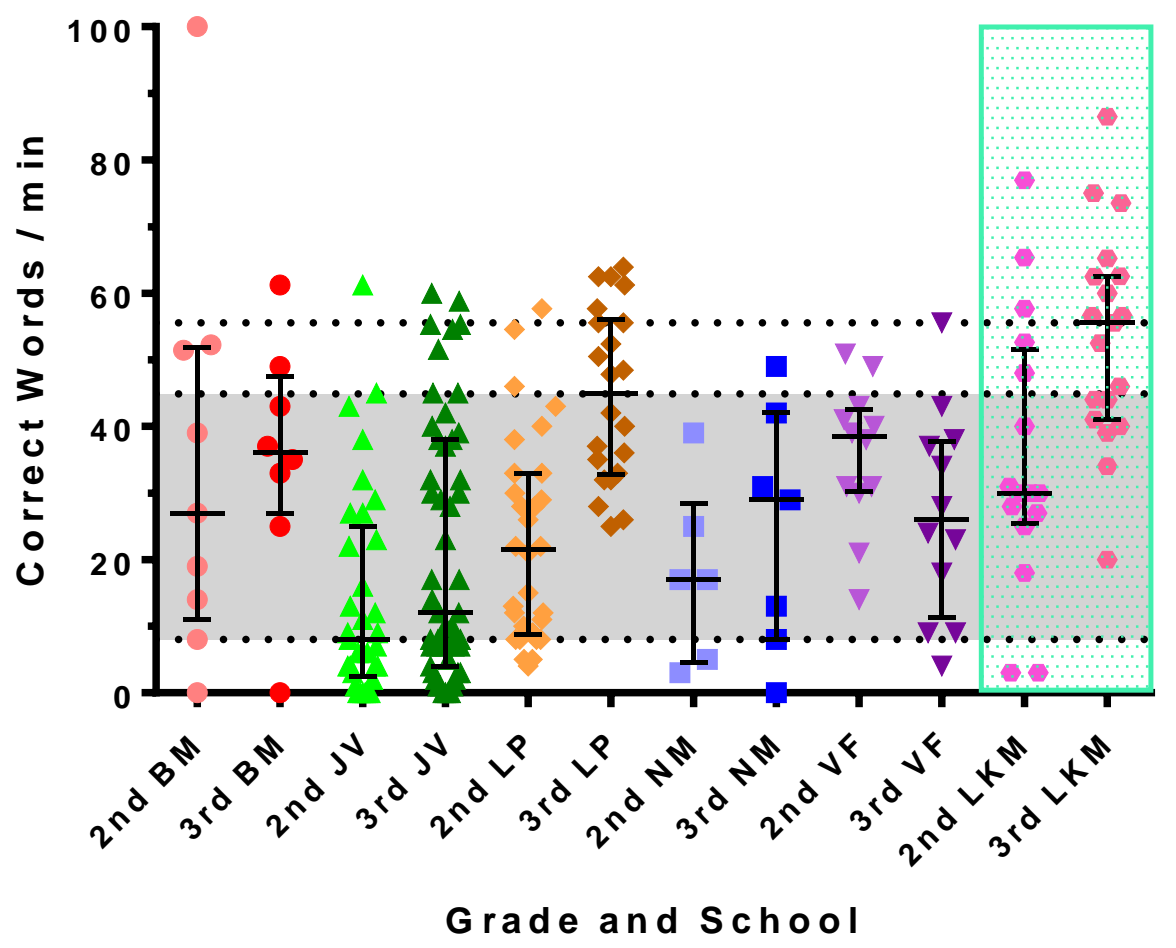

Figure 4a. Reading of familiar words in final evaluation (2014) 
In Figure 4a, the median scores for the second and third graders in the five non-LKM schools in 2014 range between 8 and 44.9 words per minute (see grey shade in the graph).

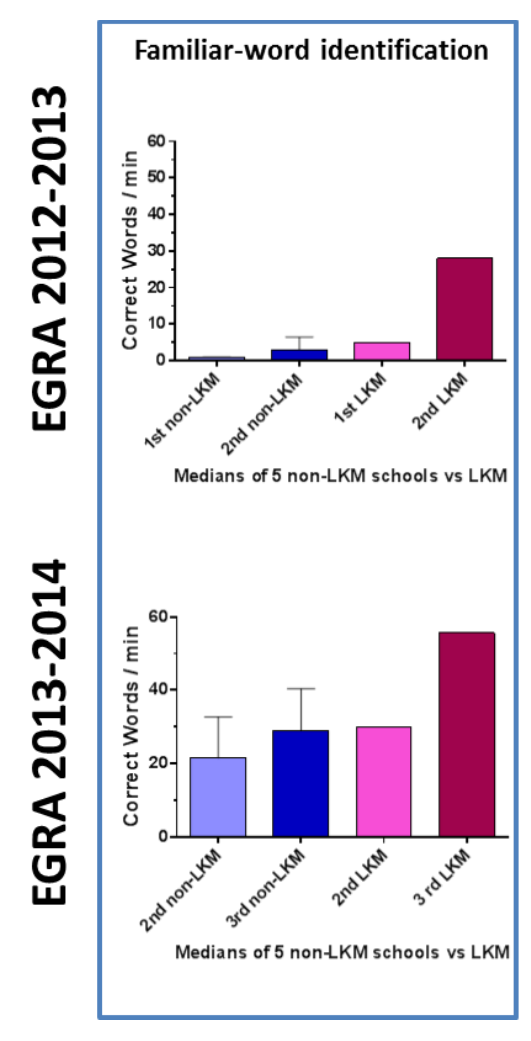

Figure 4b. LKM/non-LKM medians for familiar-word identification from baseline assessment (2012-2013, top graph) to final evaluation (2013-2014, bottom graph)

Back in 2012-2013, the results from the tests of the first and second graders in the non-LKM schools were very low: 1 and 3 correctly-read words per minute (Figure $4 \mathrm{~b}$, top graph, light and dark blue bars), respectively, as compared to the respective median scores of 5 and 28 for the first and second graders at LKM (Figure 4b, top graph, light and dark magenta bars). But, in 2013-2014, the respective medians for the second and third graders in the non-LKM schools 
(i.e., the medians of the 5 medians for each grade) narrowed the gap vis-à-vis their LKM counterparts: 21.5 and 29 (Figure 4b, bottom graph, light and dark blue bars), as compared to 30 and 55.56 (Figure 4b, bottom graph, light and dark magenta bars).

Decoding of invented words (Figures $5 a$ and $5 b$ )

In this subtest, we asked the student to read each word in isolation from a sequence of 50 invented words that were created in such a way that the student could not rely on context or memory for decoding the stimuli. Such invented words force the student to rely on his/her knowledge of grapheme-phoneme correspondences in order to decode the word and read it aloud. In this subtest, a student's giving incorrect answers for the first five words triggers the Tangerine's autostop feature.

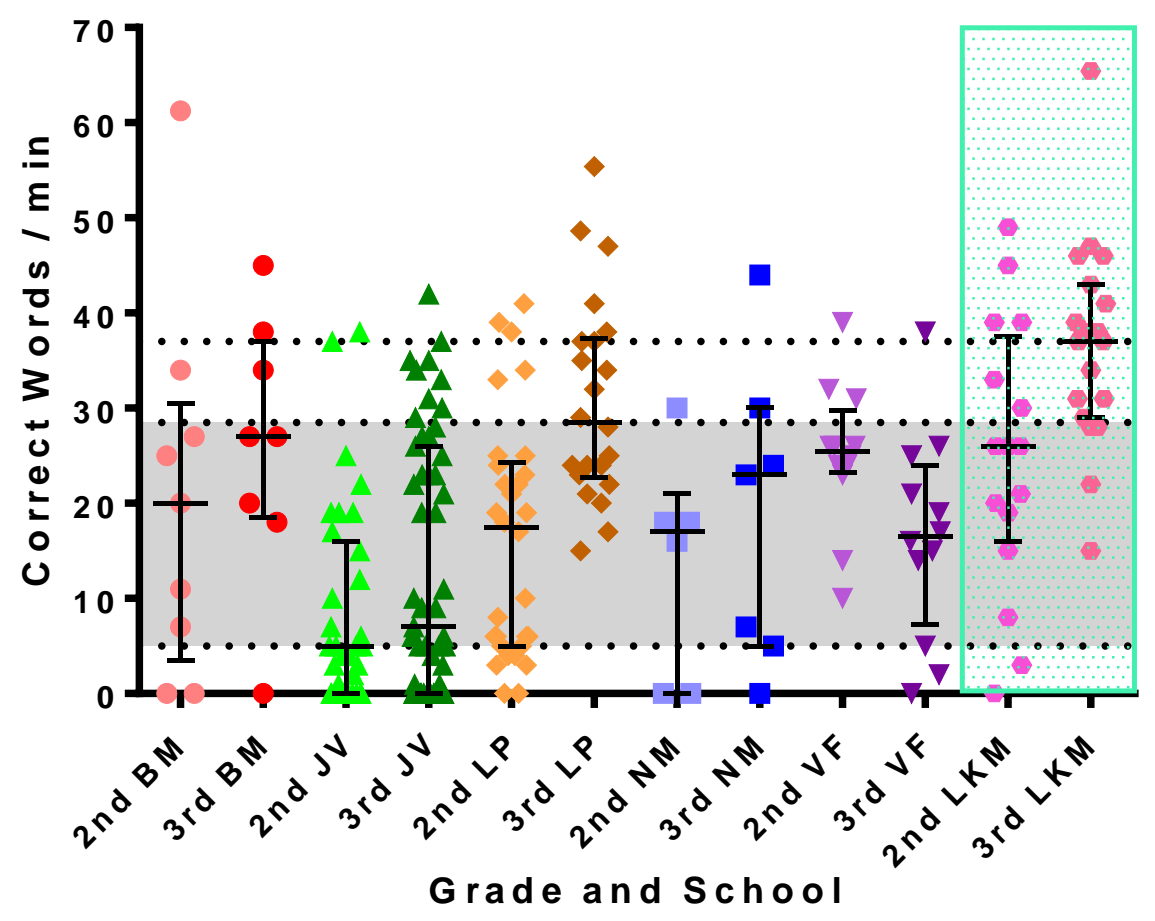

Figure 5a. Reading of invented words in final evaluation (2014) 
In Figure 5a, the set of median scores for the second and third graders in all five nonLKM schools in 2013-2014 falls in the range of 5-28 correct words per minute (see grey shade in the graph).

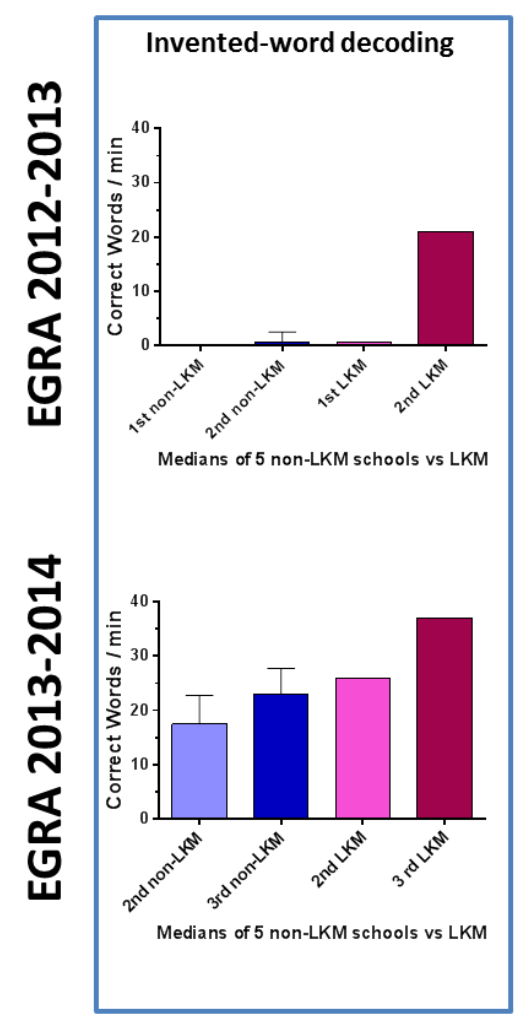

Figure 5b. LKM/non-LKM medians for invented-word decoding from baseline assessment (2012-2013, top graph) to final assessment (2013-2014, bottom)

In this subtest as well, median scores for the first and second graders in 2012-2013 (i.e., medians of the 5 medians for each grade) were extremely low ( 0 and 0.5 , respectively; Figure $5 \mathrm{~b}$, top graph, light and dark blue bars) as compared to the medians of their LKM counterparts (0.5 and 21; Figure 5b, top graph, light and dark magenta bars). Here, as well, we see substantial progress in 2013-2014, with a narrowing of the performance gap between non-LKM and LKM schools: 17.5 and 23 for second and third graders, respectively, at non-LKM schools (Figure 5b, bottom 
graph, light and dark blue bars) versus 26 and 37, respectively, for their counterparts at LKM

(Figure 5b, bottom graph, light and dark magenta bars).

Reading of short story (Figures 6a and 6b)

In this subtest, the student reads aloud a short story (61 words). Here, the students' misreading of the first 11 words of the story triggers Tangerine's autostop feature.

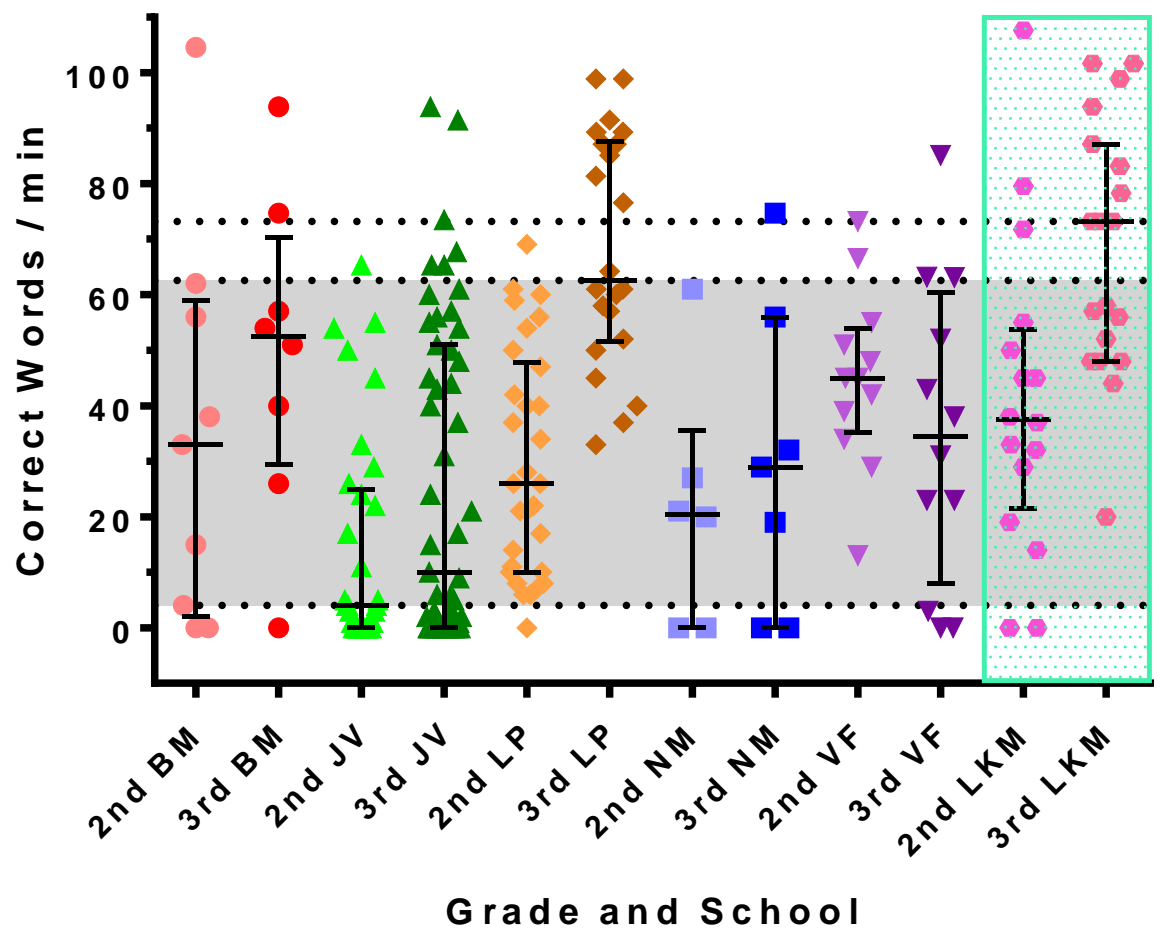

Figure 6a. Short-story reading scores in final evaluation (2014)

In Figure 6a, the median scores for the second and third graders in all five non-LKM schools in 2013-2014 range between 4 and 62.6 words per minute (see grey shade in the graph). 


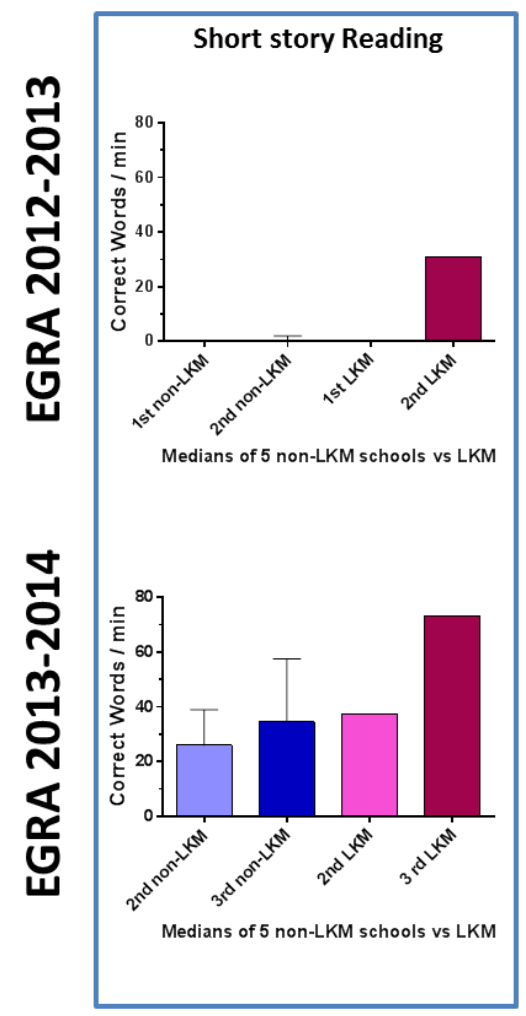

Figure 6b. LKM/non-LKM medians for short-story reading from baseline assessment (2012-2013, top) to final evaluation (2013-2014, bottom)

In 2012-2013, the median scores for the first and second graders for this subtest (i.e., the medians of the 5 medians for each grade) were extremely low: they were both 0 correct words per minute (Figure 6b, top graph, light and dark blue bars) — whereas, the medians for the LKM first and second graders were 0.5 and 31, respectively (Figure 6b, top graph, light and dark magenta bars). In two non-LKM schools (École Nationale Mare-Sucrin and Vision Fred), almost all the students were unable to read even a single word.

As Figure 6b (bottom graph) shows, the gap between LKM and non-LKM schools has narrowed in 2013-2014, with the medians among the non-LKM pupils now 26 and 34.5 for second and third graders (Figure 6b, bottom graph, light and dark blue bars), respectively, as 
compared to 37.5 and 73.2 for their LKM counterparts (Figure 6b, bottom graph, light and dark magenta bars).

We see another striking result when comparing the reading-performance data from our study with their analogues from the 2010 World Bank/USAid study (Messaoud-Galusi and Miksic 2010), where the third graders showed an average of less than 23 words/minute when reading a short story. In comparison, the pupils in the MTB project show averages of 26 words/minute for the third graders of the lowest-performing school (Joli Verger; Figure 6a, dark green upper triangles) to 62.6 and 73.2 words/minute for the third graders of the best performing schools (La Pléïade and LKM, respectively; Figure 6A, brown diamonds and pink hexagons, respectively).

Short-story reading comprehension (Figures $7 a$ and $7 b$ )

In this subtest, the enumerator asks the students five questions that test their comprehension of the story they have just read - after the enumerator removes the story from their sight. The students are only asked about the part of the story that they have read. 


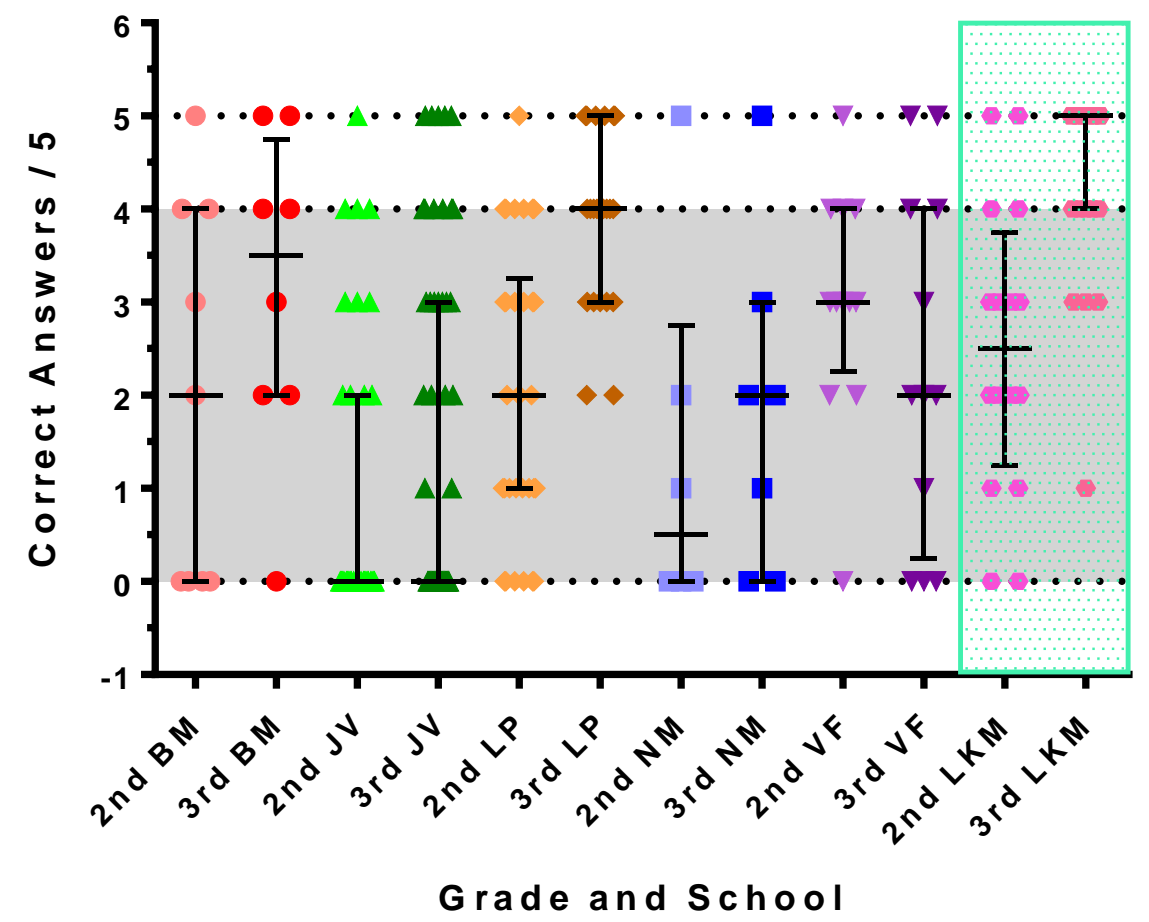

Figure 7a. Short-story reading comprehension scores in final evaluation (2014)

In Figure $7 \mathrm{a}$, the median scores for the second and third graders in the five non-LKM schools in 2013-2014 range between 0 and 4 correct answers out of 5 (see grey shade in the graph). 


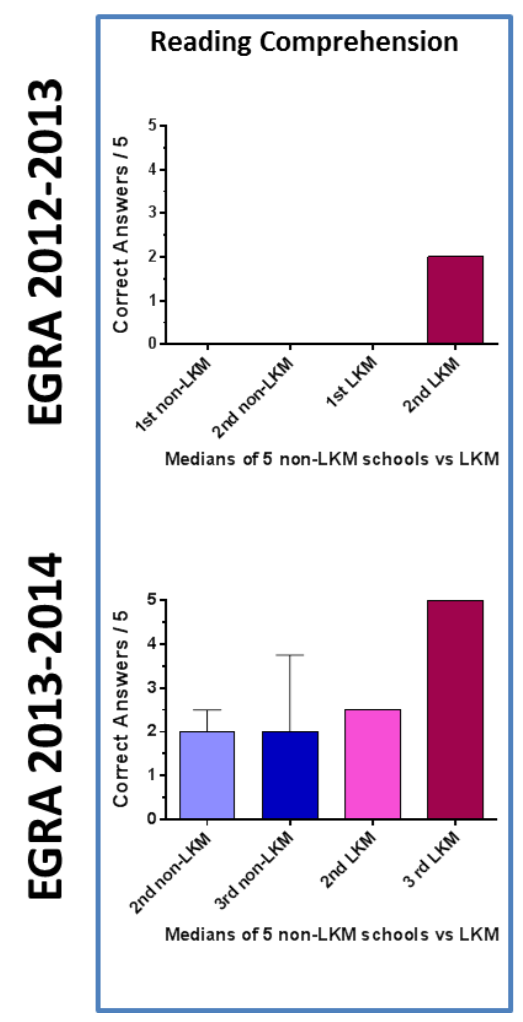

Figure 7b. LKM/non-LKM medians for reading comprehension from baseline assessment (2012-2013, top graph) to final evaluation (2013-2014, bottom graph)

In 2012-2013, most of the first and second graders in the five non-LKM schools could not give any correct answer. The median scores for those schools (i.e., the medians of the 5 medians for each grade) were 0 out of 5 in both first and second grades (Figure 7b, top graph, light and dark blue bars); whereas, the LKM students had medians of 0 out of 5 for first grade and 2 out of 5 for second grade (Figure 7b, top graph, light and dark magenta bars). In 20132014, the gap between LKM and non-LKM schools lessens: the second and third grades at the non-LKM schools both have a median of 2 correct answers out of 5 (Figure $7 \mathrm{~b}$, bottom graph, light and dark blue bars); as compared to LKM, where the second grade has a median of 2.5 out of 5 , and the third grade has a median of 5 out of 5 (Figure 7b, bottom graph, light and dark magenta bars). 
We see another striking result when one compares the reading-comprehension data from our study with their analogues from the 2010 World Bank/USAid study (Messaoud-Galusi and Miksic 2010), where the third graders showed an average of $17 \%$ comprehension when answering questions about a short text from a similar EGRA instrument. In comparison, the students in the MTB project show averages of $31 \%$ for the third graders of the lowest-performing school (Joli Verger) to $77 \%$ and $84 \%$ for the third graders of the best performing schools (La Pléïade and LKM, respectively).

\section{Oral-story comprehension (Figures $8 a$ and $8 b$ )}

In this subtest, the enumerator reads a short story to the student. The numerator reads the story twice and then asks five questions in order to test the student's comprehension of the story.

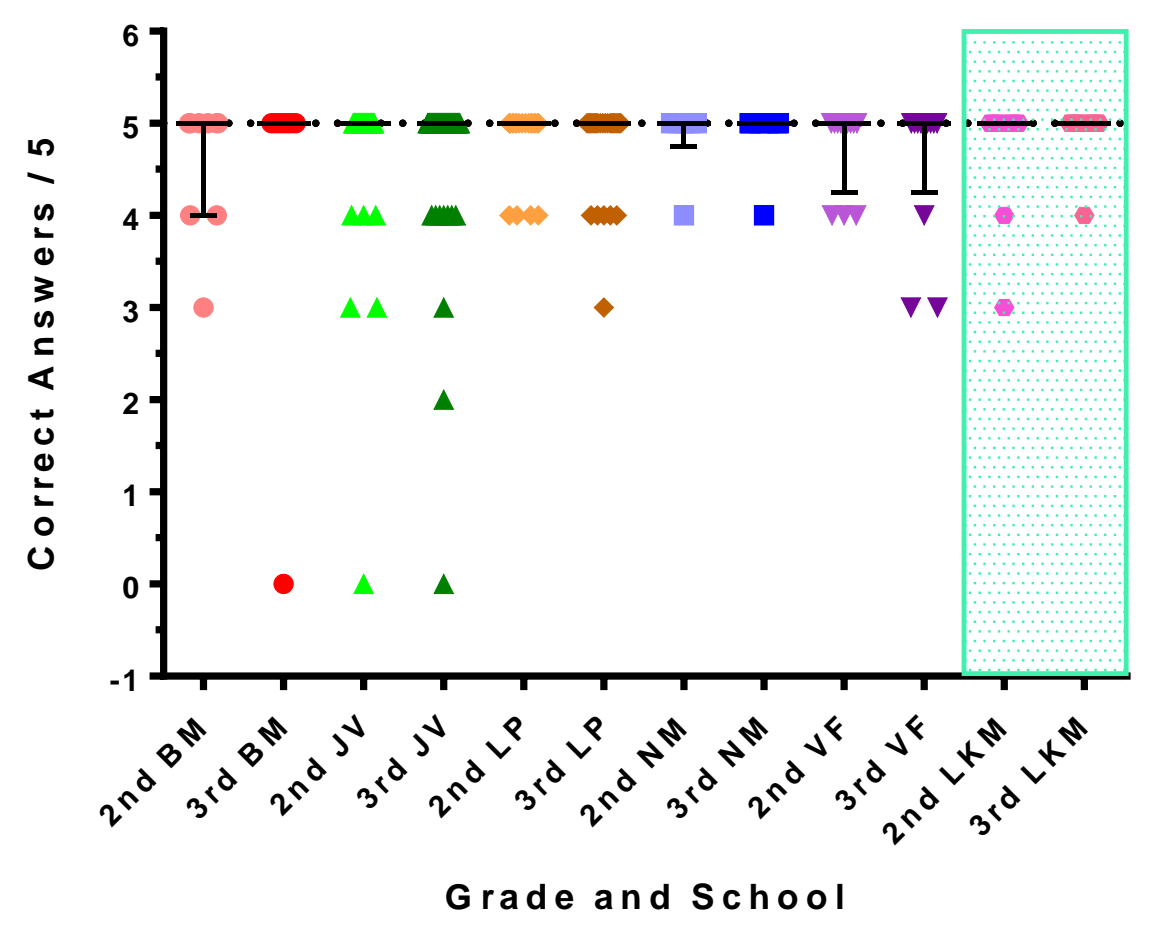

Figure 8a. Oral-story comprehension in final evaluation (2014) 
In Figure 8a, both second and third graders in all the schools (both LKM and non-LKM) have a median of 5 correct answers out of 5 .

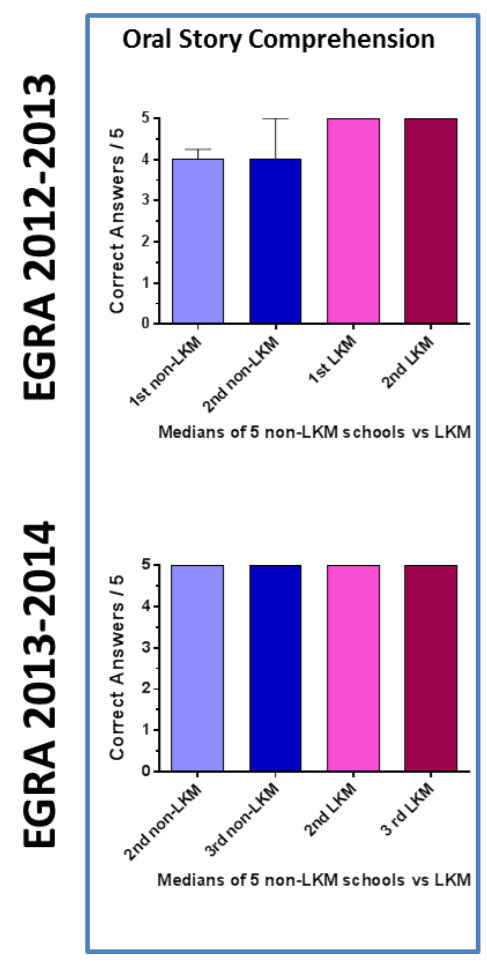

Figure 8b. LKM/non-LKM medians for oral-story comprehension from baseline assessment (2012-2013, top graph) to final (2013-2014, bottom graph)

In 2012-2013, this oral-story comprehension subtest was the only one where the LKM and nonLKM pupils showed similar performances: both the first and second graders at the non-LKM schools had medians of 4 correct answers out of 5 (Figure 8b, top graph, light and dark blue bars), where the LKM first and second grades both had a median of 5 out of 5 (Figure 8b, top graph, light and dark magenta bars). (Recall that the non-LKM medians refer to the medians of the 5 medians for each grade.) As we noted in the baseline report (DeGraff 2013b), the similar performances in listening comprehension suggest that the LKM pupils are not inherently smarter than the non-LKM pupils. Indeed, listening comprehension, unlike literacy, is a skill that all of 
the pupils, whether at LKM or elsewhere, are equally good at, independently of their respective reading levels. This led us, in the baseline report, to suggest that one likely reason why the LKM pupils had better scores on tests involving reading skills but not on oral comprehension is that the LKM pupils have benefitted from the MTB methods in terms of learning gains in reading. But now, with the 2013-2014 results at hand, it seems to us that improved reading skills can actually help improve listening comprehension as well. This is suggested by the comparison of the LKM versus non-LKM medians across baseline versus final evaluation: at the final evaluation in 2014, the second and third grades at both LKM (Figure 8b, bottom graph, light and dark magenta bars) and the non-LKM schools (Figure 8b, bottom graph, light and dark blue bars) had medians of 5 out of 5 .

\section{Summary of findings}

We now have a solid data set to document the impact of the MTB intervention on the reading levels of two cohorts of children, starting with baseline assessment data about first and second graders in 2012-2013 (for a total of 255 students), then comparing this baseline with a final evaluation of the same cohort of students in second and third grades in 2013-2014 (a total of 225 students, due to a net increase in new enrollments). As documented in the graphs above, the nonLKM pupils in these cohorts have narrowed the reading-assessment gap vis-à-vis their LKM counterparts.

These results are made even clearer when we compare the performance of the non-LKM second graders in academic year 2012-2013 with the performance of the LKM second graders in academic year 2013-2014. Each graph in Figures 9a and 9b, on the next two pages, has two horizontal lines, in dashes: the lowest line is the highest median across all the non-LKM schools 
for 2012-2013, and the highest line is the highest median across all the non-LKM schools for 2013-2014. With all the graphs taken together, it is apparent that, for each EGRA subtest, the medians of the second graders across all non-LKM schools have improved with time, whereas the medians of the second graders in LKM have remained quite similar overall. 


\section{Letter Knowledge}

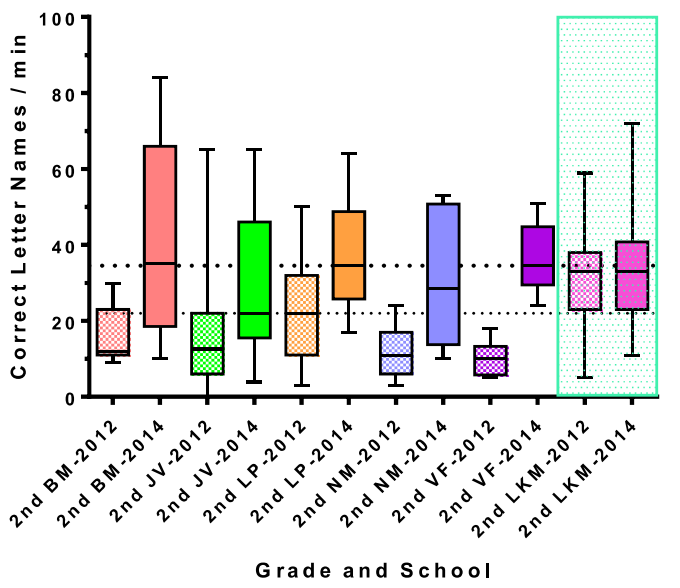

Letter Sound Knowledge

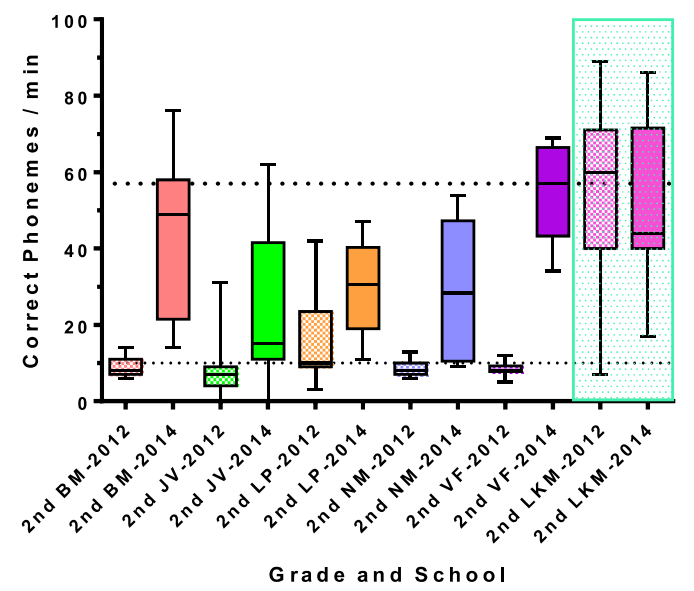

Initial Sound Knowledge

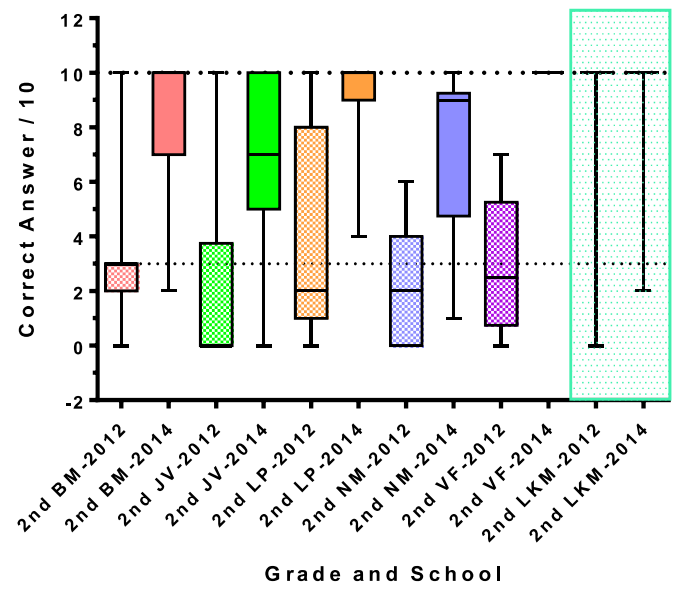

Familiar Word Knowledge

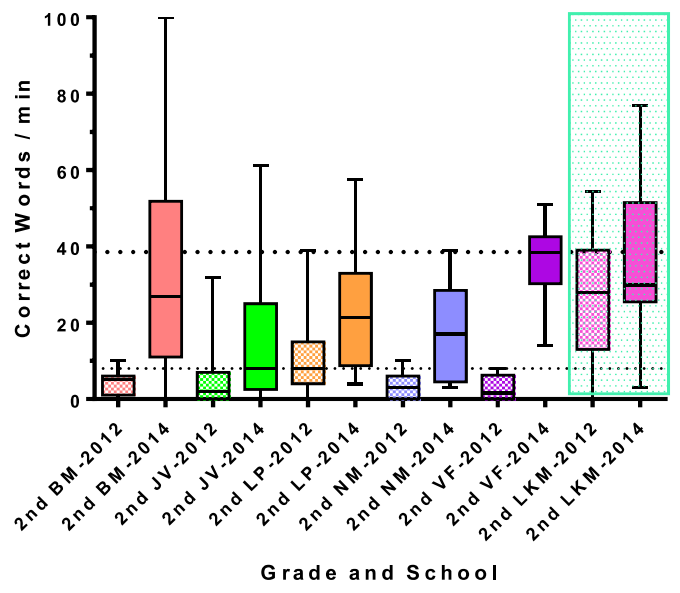

Figure 9a. EGRA scores for 2nd graders in 2012-2013 vs. 2013-2014 (I) 
Invented Word Knowledge

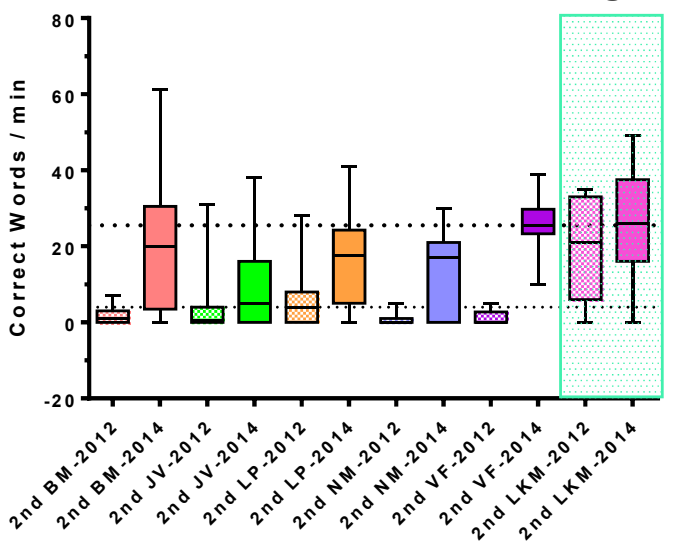

Grade and School

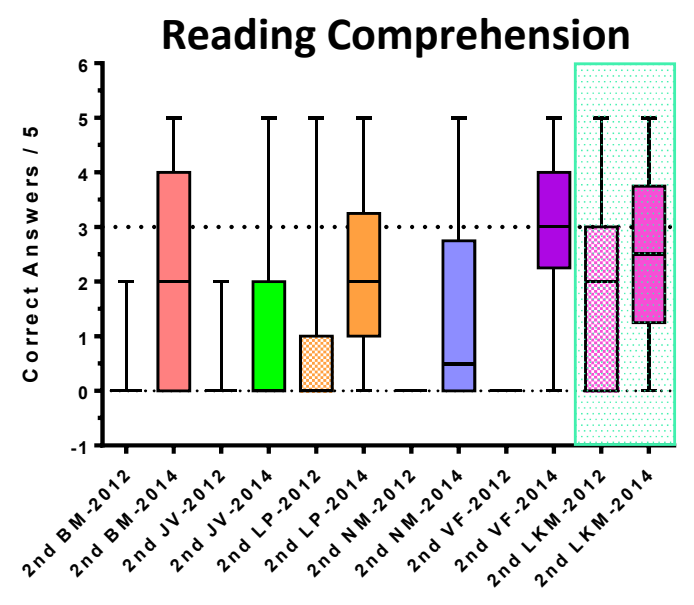

Grade and School
Story Reading
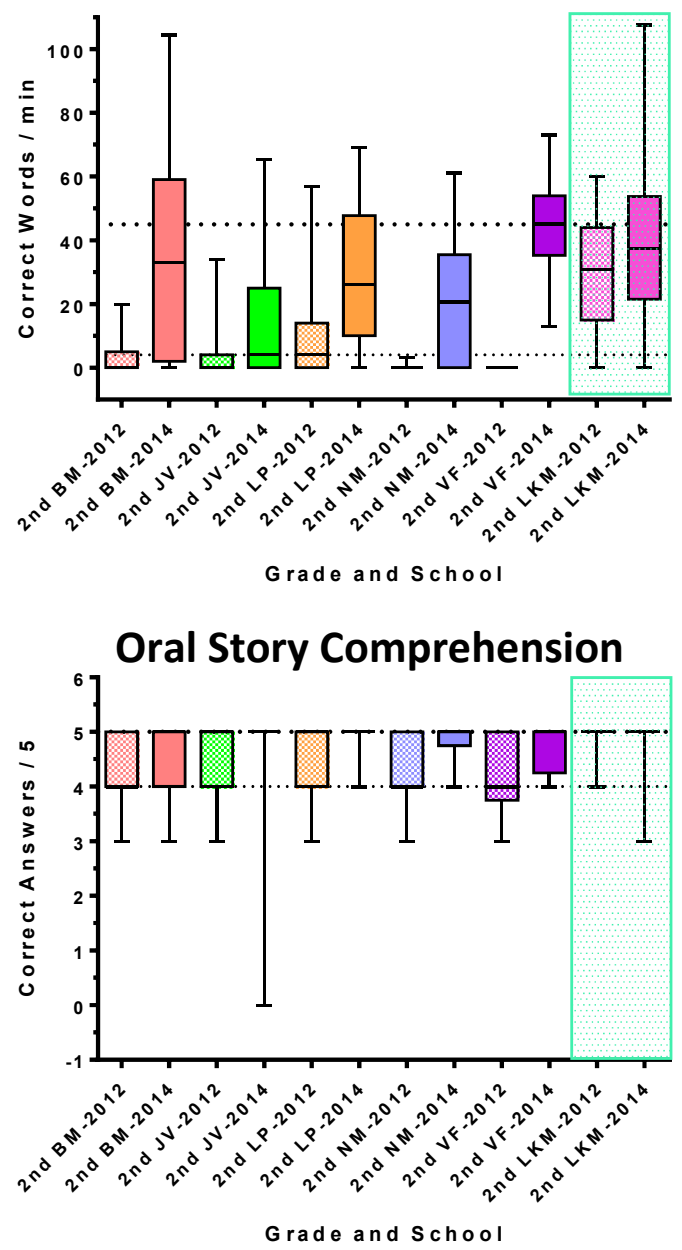

Figure 9b. EGRA scores for 2nd graders in 2012-2013 vs. 2013-2014 (II)

To recapitulate, the two cohorts of second graders at LKM (i.e., second graders in 20122013, then second graders in 2013-2014) performed similarly across the academic years. Compared to LKM's second graders, the second graders in the non-LKM schools have consistently improved their performance from one academic year to the next.

The data below (Figure 10) further illustrates the progress of the non-LKM schools. 


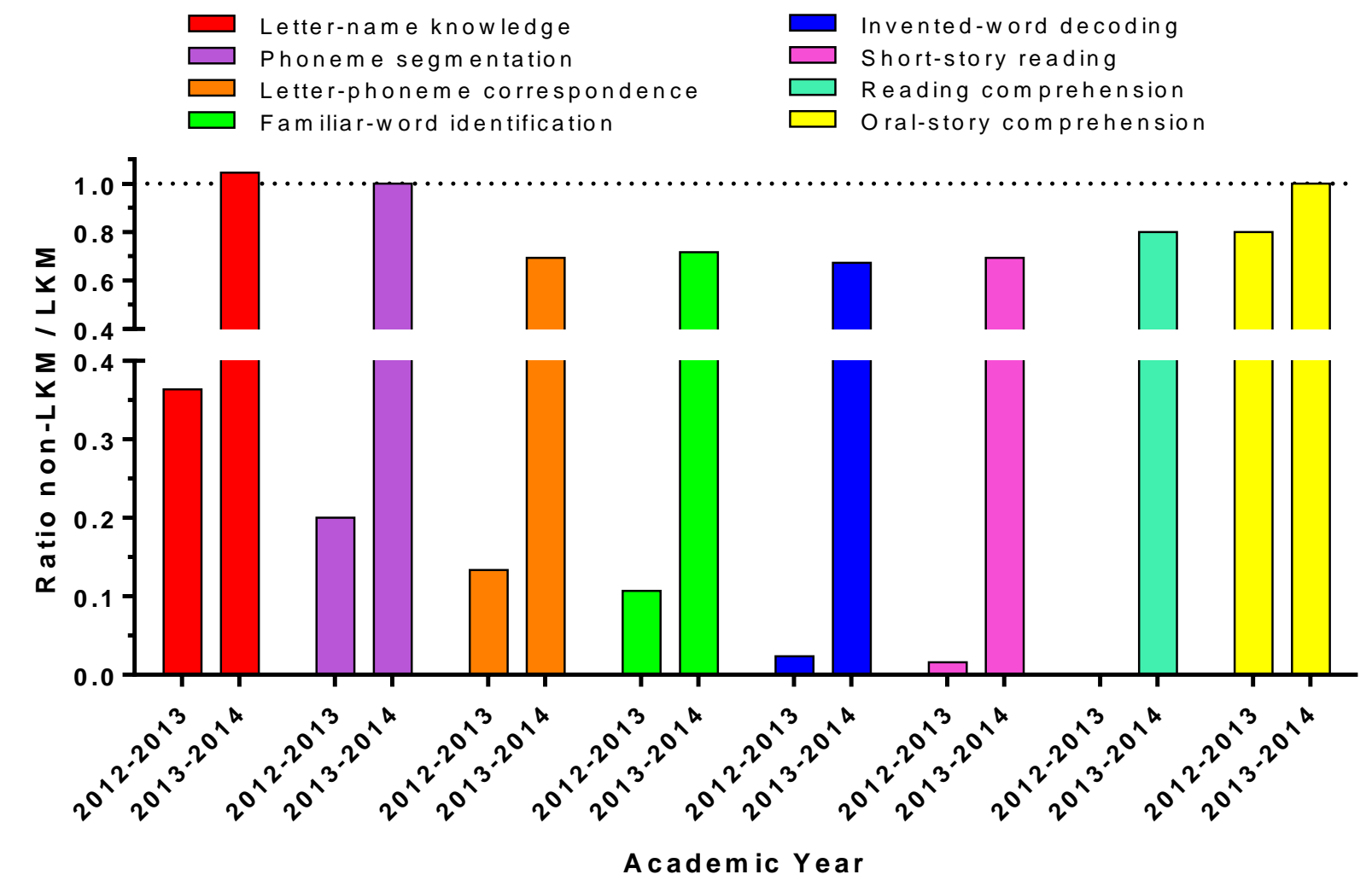

Figure 10. Non-LKM/LKM ratio of medians on each EGRA subtest for 2nd graders in 20122013, then 2nd graders in 2013-2014

We generated the graph in Figure 10 by dividing, for each EGRA subtest, the median of the non-LKM pupils' scores by the median of the LKM pupils' scores. For each subtest, we have the non-LKM/LKM ratio for academic year 2012-2013 followed by the ratio for academic year 2013-2014. A ratio of 1, as indicated by the horizontal line in dashes, would indicate an (approximately) equal performance across LKM and non-LKM students. Values below 1 indicate that the median of LKM is higher than the median of the non-LKM schools for the different EGRA subtests, which is most apparent for academic year 2012-2013. From Figure 10 as well, it is apparent that the non-LKM pupils are progressing toward LKM-level performance. Indeed, the performance gap between LKM and non-LKM schools has been reduced across all 
subtests - with the non-LKM-to-LKM ratio of scores increasing toward a ratio of 1 in 20132014.

\section{Conclusion}

On the education front in Haiti, one of the most impressive accomplishments of the government of President Michel Martelly and former prime minister Laurent Lamothe has been the welcome continuation of a trend started by preceding governments, concerning access to education. Indeed, access to primary schools has increased from 47\% in 1993 to $88 \%$ in 2013 (UNESCO 2013). But now the key question facing this and future governments concerns the quality of the content of education being provided to the increasing numbers of students. What are the children learning, if anything, and how are they learning?

The results reported in this article suggest that the MTB-based methods have, indeed, helped improve the reading levels of the students in the study. This article thus confirms the results of previous research that has provided "evidence that educational policy on language of instruction may, in fact, be the most salient explanatory variable in explaining the widely observed deficit in reading skill development in [low income] countries" (Walter 2013, p. 265). The literacy gains that I've described here thus highlight some of the necessary conditions for successful literacy programs in Haiti. This is a key issue for sustainable development in Haiti in light of the fact that reading is perhaps the most important skill to be acquired in early grades. Children need to learn how to read so they can eventually read in order to learn. Cognitive science teaches us that the child's brain, from the womb onward, is formatted by the ambient language to recognize the phonemic structure of that language; in turn, it is such phonological awareness vis-à-vis the native language that helps the child establish robust 
correspondence between texts, sounds, and semantics when the child learns to read in that native language (Dehaene, Dehaene-Lambertz, Gentaz, Huron, and Sprenger-Charolles 2011). Such capacity, and opportunity, to learn to read in one's native language is, in turn, a necessary condition for individual and national academic and socioeconomic development.

It thus seems imperative that the state require schools to make systematic use, throughout the country, of student-centered Kreyòl-based active-learning approaches, similar to the Mother Tongue Books project, for the teaching of reading and writing — and for every other academic field as well, especially science and mathematics (see DeGraff 2013a; DeGraff and Ruggles 2014; Dejean 2006; Jean-Pierre 2016; Neyfakh 2011). This is, in fact, what's legally required of the Haitian state by Haiti's Constitution of 1987 which declares, unambiguously, that Kreyòl is the one language that bonds all Haitians together. Moreover, the Constitution assigns as "the first responsibility of the state [...] the education of the masses, which is the only way the country can be developed". We are not arguing to exclude French (Haiti's other official language) from Haiti's classrooms. Our argument is that the optimal language to teach in is the children's mother tongue, which is Kreyòl for the vast majority in Haiti—as it is in such countries as Finland, Norway, and Korea, where their national language (Finnish, Norwegian, Korean) is also the primary language of school instruction. Of course, French, as a so-called international language, should be taught to Haitian children — as a second language. Given Haiti's geographical position, English and Spanish, as well, should be taught as second languages. And one should also consider the fact that Kreyòl, too, especially in the Americas, does function as an international language to the extent that Kreyòl speakers outnumber French speakers in that region (Mathieu 2005). 
If Kreyòl continues to be marginalized in Haiti's education system, the country will continue wasting its most precious resource - namely, the academic readiness of its youth, whose brains are wired, from birth, to decode the phonemic and grammatical structure of Kreyòl, their sole mother tongue and an indispensable tool for learning. In Haiti, some $50 \%$ of the population is under age 25; our youth is, in the words of Nesmy Manigat, Haiti's former minister of national education, a "demographic bonus" - one that must be used, through Kreyòl-based education, for Haiti's development lest this youth become a "demographic bomb".

This demographic bomb is not a threat to Haiti alone. Some 200 million children worldwide are not formally taught in their native languages; these children, therefore, cannot have full access to quality education. Globally, over 2 billion people speak languages that are marginalized in, or outright excluded from, classrooms (Dutcher 2004; Walter and Benson 2012; UNESCO 2016). Our hope is that the results reported in this article will help to usher in a deep global change in attitudes toward local languages and create better conditions for their use in education, especially for communities that need to reclaim their native languages for their cultural and psychological well-being and for sustainable development.

The good news is that the Mother Tongue Books intervention I describe here not only can scale up to all of Haiti but can also have a deep transformative impact on countries and communities throughout the world, including migrant communities in the U.S., that are disenfranchised by exclusionary linguistic and pedagogical practices. Such interventions, based on the innovative and systematic use of local languages, will open up quality education to radically new levels, toward a better world. 


\section{Appendix: A proposal for letter names in Kreyòl}

Typically, Haitian pupils are taught to memorize the French letter names, which they use even as they learn how to read in Kreyòl. This application of the French letter names to Kreyòl's official 32-grapheme alphabet as described in Bernard (1980) is problematic in light of the fact that the grapheme-to-phoneme mapping in Kreyòl is substantially different from, and much more regular than, its counterpart in French.

Consider, say, the letter "g", whose name is pronounced [ ze ] in French with the corresponding phoneme / 3 / occurring in words like orange, though "g" is pronounced / g / at the beginning of a French word such as "garçon". Now, compare the phonemic characteristics of the same letter "g" in Kreyòl. In Kreyòl, this letter "g", in the continuous reading of written words, is uniformly pronounced / $\mathrm{g} /$ as in gaga. Therefore, applying the French letter name [ ze ] to Kreyòl "g" is misleading since it obscures the relationship between the grapheme $\langle\mathrm{g}>$ and its associated phoneme / g /. Indeed, the Kreyòl letter "g", unlike the French letter "g", always corresponds to the phoneme / $\mathrm{g} /$ and never corresponds to the phoneme / 3 /.

Similar considerations apply to the letter "c", whose name is pronounced [se] in French. However, in Kreyòl, the letter "c" is not even a grapheme in the official alphabet. In Kreyòl, the letter "c" occurs, as a graph, only in combination with "h" to create the grapheme $<\mathrm{ch}>$, a digraph that corresponds to the phoneme / $\check{s} /$. Therefore, it is misleading to identify the letter "c" with the letter name [se] since the consonant / s / in [se] never matches the pronunciation of the letter "c" in Kreyòl—a letter that is never pronounced alone since, as noted above, it is not a grapheme in the alphabet

The French letter names present a more general disadvantage vis-à-vis the Kreyòl alphabet. Consider the fact that the vowel that accompanies the consonants in the French letter 
names is either / e / as in "b", "c", “d”, etc; / a / as in "h", "k"; / ع / as in "l", “m”, "n"; / i / as in “j”, "x"; / y / as in "q". Furthermore, the supporting vowel is pronounced either after the consonant (as in "b”, “c”, “d”, etc.) or before (as in "h", “l”, “m”, “n”, etc.).

Louis-Charles, Telfort, and DeGraff (2015) have proposed an alternative set of letter names for Kreyòl, consisting of two segments for most of the consonants: the consonant itself followed by the supporting vowel / a / in a consonant+vowel template that is easiest for pronunciation by small children (Jakobson 1960). Such a system is much more regular than the French letter names and more consistent with the transparent phonemic structure of the Kreyòl orthography. Indeed, the Kreyòl orthography exhibits a virtually "transparent" one-to-one relationship between graphemes and phonemes; whereas, French orthography is "opaque", with a many-to-many relationship between graphemes and phonemes. Research on the advantages of transparent orthographies for developing children's phonemic awareness (Dehaene et al. 2011), indicates that having the Kreyòl alphabet's letter names be most transparent will help raise the phonemic awareness of Kreyòl-speaking children. This is a considerable advantage for learning to read in Kreyòl in Haiti. This advantage also helps dyslexic children, who show fewer deficits with transparent orthographies (as in Spanish) than with opaque orthographies (Brunswick, McDougall, and De Mornay Davies 2010; Lallier, Valdois, Lassus-Sangosse, Prado, and Kandel 2014).

Furthermore, because of its phonetic acoustic and stochastic properties, there is a pedagogical virtue in using the vowel /a/ as the supporting vowel for the consonant: among all the vowels in Kreyòl, /a/ is the vowel that makes the consonants most perceptible and most easily pronounceable (Jakobson 1960; also see Krull 1988 on the identification of consonants across different vocalic contexts; I am grateful to Benjamin Storme (graduate student at MIT 
Linguistics) for sharing with me his own research on this topic, including his calculations, based on Krull 1988, showing that the vowel / a / is the one that, in the neighborhood of consonants, leads to the least errors in the identification of these consonants.). Lastly, the vowel /a/ is the most frequently occurring vowel in Kreyòl (Hebblethwaite 2009), which implies that its use in Kreyòl letter names will make it even easier for children to produce and remember these names and the letter-sound correspondences they illustrate. Such templates for the names of Kreyòl consonants (consonant + / a /) can, thus, serve to enhance Kreyòl-speaking children's phonemic awareness.

\section{References}

Arthus, W. W. (2012). La machine diplomatique française en Hä̈ti: 1945-1958. Paris:

\section{L'Harmattan.}

Arthus, W. W. (2014). Duvalier à l'ombre de la guerre froide: Les dessous de la politique étrangère d'Haïti (1957-1963). Port-au-Prince, Haïti: L’Imprimeur S.A.

Babaci-Wilhite, Z. (2014). Local language as a human right in education: Comparative cases from Africa. In A. Pittman \& M. A. Pereyra (Series Eds.), Comparative and international education: A diversity of voices (vol. 36). Rotterdam: Sense.

Bernard, J. C. (1980). Communiqué du Département de l'Éducation Nationale au sujet de l'orthographe du créole. Port-au-Prince, Haïti: Secrétairerie d'État de l'Éducation Nationale.

Blommaert, J., \& Rampton, B. (2011). Language and superdiversity. Diversities, 13(2). www.unesco.org/shs/diversities/vol13/issue2/art1 
Brunswick, N., McDougall, S., \& De Mornay Davies, P. (2010). Reading and dyslexia in different orthographies. Hove, East Sussex: Psychology Press.

CIA [Central Intelligence Agency] (2016). World fact book. Washington DC: Central Intelligence Agency. https://www.cia.gov/library/publications/the-worldfactbook/geos/ha.html

DeGraff, M. (2005). Linguists' most dangerous myth: The fallacy of Creole exceptionalism. Language in Society, 34(4): 533-591. http://web.mit.edu/linguistics/people/faculty/degraff/degraff2005fallacy_of_creole_excep tionalism.pdf

DeGraff, M. (2009). Creole exceptionalism and the (mis-)education of the Creole speaker. In JA. Kleifgen \& G. Bond (Eds.), The languages of Africa and the diaspora (pp. 124-144). Bristol, UK: Multilingual Matters. http://web.mit.edu/linguistics/people/faculty/degraff/degraff2009creole_exceptionalism_a nd the mis_education_of the_creole_speaker.pdf

DeGraff, M. (2013a). MIT-Haiti initiative uses Haitian Creole to make learning truly active, constructive, and interactive. Educational Technology Debate, July. http://bit.ly/1HezJEL

DeGraff, M. (2013b). Mother-Tongue Books: Learning to read in Haiti. Baseline survey report on reading levels. Report submitted to All Children Reading: A Grand Challenge for Development, March 13. http://allchildrenreading.org/

DeGraff, M. (2014). The ecology of language evolution in Latin America: A Haitian postscript toward a postcolonial sequel. In S. Mufwene (Ed.), Iberian imperialism and language evolution in Latin America (pp. 274-327). Chicago: University of Chicago Press. 
http://web.mit.edu/linguistics/people/faculty/degraff/degraff_2014_ecology_of_language _evolution_in_latin_america.pdf

DeGraff, M. (2015a). France's misconceived “Marshall Plan” for Haiti. Le Monde Diplomatique, May 26.

http://mondediplo.com/outsidein/france-s-misconceived-marshall-plan-for-haiti

DeGraff, M. (2015b). Kreyòl-based and technology-enhanced learning of reading, writing, math, and science in Haiti: Project outcomes report. Washington, DC: National Science Foundation. http://1.usa.gov/1JUdvpt

DeGraff, M., \& Ruggles, M. (2014). A Creole solution to Haiti's woes. New York Times, Opinion Pages, August 1, 2014. http://www.nytimes.com/2014/08/02/opinion/a-creole-solution-for-haitis-woes.html

Dehaene, S., Dehaene-Lambertz, G., Gentaz, É., Huron, C., \& Sprenger-Charolles, L. (Eds.) (2011). Apprendre à lire: Des sciences cognitives à la salle de classe. Paris: Odile Jacob.

Dejean, Y. (2006). Yon lekòl tèt anba nan yon peyi tèt anba. [An upside-down school in an upside-down country.] Port-au Prince: FOKAL.

Dutcher, N. (2004). Expanding educational opportunity in linguistically diverse societies. Washington, DC: Center for Applied Linguistics.

Fattier, D. (2000). Contribution à l'étude de la genèse d'un créole: L'atlas linguistique d'Haïti, cartes et commentaires. Villeneuve d'Ascq, France: Presses universitaires du Septentrion. https://www.u-cergy.fr/fr/laboratoires/labo-ldi/publications/these-creole.html

Friends of Matènwa (2012). Mother Tongue Books: Learning to read in Haiti. Proposal submitted to All Children Reading: A Grand Challenge for Development. http://allchildrenreading.org/ 
Gourgues, Jacques-Michel (2016). Les manuels scolaires en Haïti: Outils de la colonialité. Paris: L'Harmattan.

Gove, A., \& Wetteberg, A. (Eds.) (2014). The Early Grade Reading Assessment: Applications and interventions to improve basic literacy. Research Triangle Park, NC: RTI Press. http://www.rti.org/pubs/bk-0007-1109-wetterberg.pdf

GTEF [Groupe de Travail sur l'Éducation et la Formation] (Ed.) (2010). Pour un pacte national pour l'education en Haïti. Port-au-Prince: Bibliothèque Nationale.

Hebblethwaite, B. (2009). Scrabble as a tool for Haitian Creole literacy: Sociolinguistic and orthographic foundations. Journal of Pidgin and Creole Languages, 24(2): 275-305.

Hebblethwaite, B. (2012). French and underdevelopment, Haitian Creole and development: Educational language policy problems and solutions in Haiti. Journal of Pidgin and Creole Languages, 27(2): 255-302.

Huebler, F., \& Lu, W. (2013). Adult and youth literacy: National, regional and global trends, 1985-2015. Paris: UNESCO Institute for Statistics. http://www.uis.unesco.org/Education/Documents/literacy-statistics-trends-1985-2015.pdf

Jakobson, R. (1960). Why papa? Why mama? In B. Kaplan and S. Warner (Eds.), Perspectives in psychological theory: Essays in honor of Heinz Werner (pp. 124-134). New York: International Universities Press.

Jean-Pierre, M. (2016). Language and learning in a post-colonial context: A critical ethnographic study in schools in Haiti. London: Routledge, Taylor \& Francis.

Krull, D. (1988). Acoustic properties as predictors of perceptual responses: A study of Swedish voiced stops. Stockholm: Institute of Linguistics, University of Stockholm. 
Lallier, M., Valdois, S., Lassus-Sangosse, D., Prado, C., \& Kandel, S. (2014). Impact of orthographic transparency on typical and atypical reading development: Evidence in French-Spanish bilingual children. Research in Developmental Disabilities, 35(5): $1177-1190$.

Louis-Charles, M. C., Telfort, B., \& DeGraff, M. (2015). Chante alfabè kreyòl la. Pennsauken, NJ: Disc Makers.

Mathieu, S. (2005). Depi nan Ginen nèg renmen nèg. Kreyòl ak demokrasi ann Ayiti [Since Ginen, blacks love blacks: Creole and democracy in Haiti]. Port-au-Prince, Haiti: Près Nasyonal Peyi d'Ayiti.

Messaoud-Galusi, S., \& Miksic, E. (2010). Haïti: Early grade reading assessment. (EGRA): Rapport pour le Ministère de l'Éducation et la Banque Mondiale—Résultats en français et en créole. Prepared for the World Bank and USAID. Washington, DC: RTI International: Research Triangle Institute. www.eddataglobal.org/reading/index.cfm/Haiti\%20EGRA\%20Report\%20Final.pdf?fuse action $=$ throwpub $\& I D=262$

Migge, B., Léglise, I., \& Bartens, A. (2010). Creoles in education: An appraisal of current programs and projects. Amsterdam: John Benjamins.

Myers-Scotton, C. (1993). Elite closure as a powerful language strategy: The African case. International Journal of the Sociology of Language, 103(1): 149-164.

Neyfakh, L. (2011). The power of Creole. Boston Globe, Ideas section, 24 July 24. http://www.boston.com/bostonglobe/ideas/articles/2011/07/24/the_power_of_creole/?pag $\underline{\mathrm{e}=\mathrm{full}}$ 
Ortiz, I., \& Cummins, M. (2011). Global inequality: Beyond the bottom billion-A rapid review of income distribution in 141 countries. New York: United Nations Children's Fund (UNICEF). http://www.unicef.org/socialpolicy/files/Global_Inequality.pdf

RTI International (2014). Tout Timoun Ap Li: ToTAL (All Children Reading)_Final report on the capacities of organizations in the education field ouest, artibonite, nord, and nordest. Research Triangle Park, NC: Research Triangle Institute. http://pdf.usaid.gov/pdf_docs/pbaaa658.pdf

Skutnabb-Kangas, T. (1988). Multilingualism and the education of minority children. In T. Skutnabb-Kangas \& J. Cummins (Eds.), Minority education: From shame to struggle (pp. 9-44). Avon, UK: Multilingual Matters.

UNESCO (1953). The use of vernacular languages in education. Monographs on fundamental education (vol. 8). Paris: UNESCO. http://unesdoc.unesco.org/images/0000/000028/002897EB.pdf

UNESCO (2002). Regional report: Educational panorama of the Americas. Santiago, Chile: UNESCO, Regional Office for Education in Latin America and the Caribbean. http://unesdoc.unesco.org/images/0015/001593/159358E.pdf

UNESCO (2013). Objectifs du millénaire pour le développement: Haiti-Un nouveau regard. http://www.ht.undp.org/content/dam/haiti/docs/mdg/UNDP-HTHaitiRapportOMD2013_20140611.pdf

UNESCO (2016). If you don't understand how can you learn. Policy Paper 24. Paris: Global Education Monitoring Report. http://unesdoc.unesco.org/images/0024/002437/243713E.pdf 
Verner, D., \& Egset, W. (2007). Social resilience and state fragility in Haiti. Washington, DC: World Bank. http://siteresources.worldbank.org/SOCIALANALYSIS/11048941115795935771/20938696/Haiti_CSA.pdf

Walter, S. (2008). The language of instruction issue: Framing an empirical perspective. In: B. Spolsky \& F. Hult (Eds.), Handbook of educational linguistics (pp. 129-146). London: Blackwell.

Walter, S. (2013). Exploring the development of reading in multilingual education programs. In: C. Benson \& K. Kosonen (Eds.), Language issues in comparative education: Inclusive teaching and learning in non-dominant languages and cultures (pp. 265-281). Rotterdam: Sense.

Walter, S., \& Benson, C. (2012). Language policy and medium of instruction in formal education. In: B. Spolsky (Ed.), The Cambridge handbook of language policy (pp. 278300). Cambridge: Cambridge University Press.

Webb, P. (2010). Science education and literacy: Imperatives for the developed and developing world. Science, 328: 448-450. DOI: 10.1126/science.

World Bank (2014). Investing in people to fight poverty in Haiti: Reflections for evidence-based policy making. Washington, DC: World Bank Group. http://documents.worldbank.org/curated/en/222901468029372321/Reflections-forevidence-based-policy-making

Zefi, L. (2011). Edikasyon ak lang nan divès pwopozisyon plan rekonstriksyon d Ayiti [Education and language in various proposals for the reconstruction of Haiti]. In: W. Dorlus (Ed.), Entre refondation et reconstruction: Les problématiques de l'avenir postsismique d'Haïti (pp. 257-264). Port-au-Prince: Éditions de l'Université d'État d'Haïti. 
56 of 56 


\section{$\underline{\text { Author bio }}$}

Michel DeGraff (USA) is professor of linguistics at the Massachusetts Institute of Technology (MIT). He's a founding member of Haiti's Haitian Creole Academy and the director of the MITHaiti Initiative. He studies Creole languages, focusing on his native Haitian Creole (Kreyòl). His research documents major gaps in our understanding of the history and structures of Creole languages, and shows that Creole languages, erroneously believed to be "lesser languages", are fundamentally comparable to non-Creole languages. 